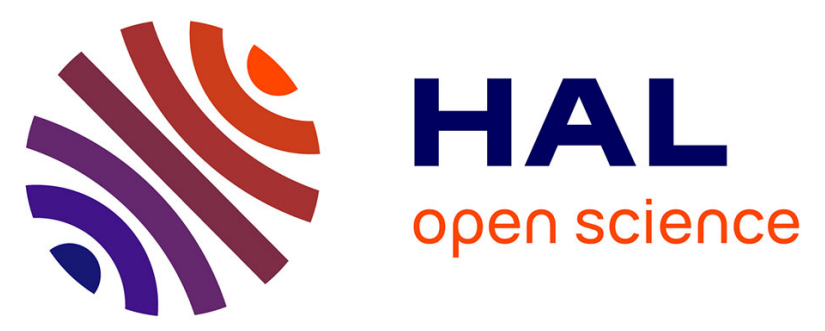

\title{
SCM, a novel M-like protein from Streptococcus canis binds (Mini)-plasminogen with high affinity and facilitates bacterial transmigration
}

Marcus Fulde, Manfred Rohde, Angela Hitzmann, Klaus T Preissner, D.Patric Nitsche-Schmitz, Andreas Nerlich, Gursharan Singh Chhatwal, Simone Bergmann

\section{To cite this version:}

Marcus Fulde, Manfred Rohde, Angela Hitzmann, Klaus T Preissner, D.Patric Nitsche-Schmitz, et al.. SCM, a novel M-like protein from Streptococcus canis binds (Mini)-plasminogen with high affinity and facilitates bacterial transmigration. Biochemical Journal, 2011, 434 (3), pp.523-535. 10.1042/BJ20101121 . hal-00569400

\section{HAL Id: hal-00569400 https://hal.science/hal-00569400}

Submitted on 25 Feb 2011

HAL is a multi-disciplinary open access archive for the deposit and dissemination of scientific research documents, whether they are published or not. The documents may come from teaching and research institutions in France or abroad, or from public or private research centers.
L'archive ouverte pluridisciplinaire HAL, est destinée au dépôt et à la diffusion de documents scientifiques de niveau recherche, publiés ou non, émanant des établissements d'enseignement et de recherche français ou étrangers, des laboratoires publics ou privés. 


\title{
SCM, a novel M-like protein from Streptococcus canis binds (Mini)-plasminogen with high affinity and facilitates bacterial transmigration
}

\author{
Marcus Fulde $^{1}$, Manfred Rohde ${ }^{1}$, Angela Hitzmann ${ }^{1}$, Klaus T. Preissner ${ }^{2}$, D. Patric Nitsche- \\ Schmitz $^{1}$, Andreas Nerlich ${ }^{1}$, Gursharan Singh Chhatwal ${ }^{1}$, and Simone Bergmann \\ ${ }^{1}$ Department of Medical Microbiology, Helmholtz Centre for Infection Research (HZI), \\ Braunschweig, Germany, ${ }^{2}$ Department of Biochemistry, Medical School, Justus-Liebig-University, \\ Friedrichstrasse 24, D-35392 Giessen
}

Running head: Interaction of $S$. canis with plasminogen Address correspondence to: Marcus Fulde, PhD, HZI, Inhoffenstrasse 7, 38124 Braunschweig, Germany. Fax (0049) 5316181 4499; E-mail: Marcus.Fulde@helmholtz-hzi.de

\section{SYNOPSIS}

Streptococcus canis is an important zoonotic pathogen capable of causing serious invasive diseases in domestic animals and humans. In this study we report the binding of human plasminogen to $S$. canis and the recruitment of proteolytically active plasmin on its surface. The binding receptor for plasminogen was identified as a novel $M$-like protein designated $S$. canis M-like protein (SCIM). Surface plasmon resonance analyses, radioactive dot blot analyses and heterologous expression on the surface of $S$. gordonii confirmed the plasminogen-binding capability of SCM. The binding domain was located within the N-terminus of SCM, which specifically bound to the C-terminal part of plasminogen (mini-plasminogen) comprising kringle domain 5 and the catalytic domain. In the presence of urokinase, SCM mediated plasminogen activation on the bacterial surface that was inhibited by serine protease inhibitors and lysine amino acid analogues. Surface-bound plasmin effectively degraded purified fibrinogen as well as fibrin clots, resulting in the dissolution of fibrin thrombi. Electron microscopic illustration and time lapse imaging demonstrated bacterial transmigration through fibrinous thrombi. This study led for the first time to the identification of SCM as novel receptor for (mini)-plasminogen mediating fibrinolytic activity of $S$. canis.
Key words:

Streptococcus canis, M-like protein, miniplasminogen, transmigration

Abbreviations:

6-AHA, $\varepsilon$-amino caproic acid; ECM, extracellular matrix; $\mathrm{K}(1-3,1-4,4)$, kringle (1-3, $1-4,4)$; LB, Luria Bertani; mPLG, miniplasminogen; PAM, plasminogen-binding group A streptococcal M protein; PLG, plasminogen; SCM, S. canis M-like protein; tPA, tissue-type plasminogen activator; TSB, Tryptic-Soy broth; uPA, urokinase-type plasminogen activator

\section{INTRODUCTION}

S. canis belongs to group $\mathrm{G}$ streptococci and represents a common member of the resident microflora of skin and mucosa of various animals [1]. It is considered as an opportunistic zoonotic pathogen capable of causing serious invasive diseases such as streptococcal toxic shock syndrome, necrotizing fasciitis, septicemia and meningitis in domestic animals [2] as well as humans [3-5]. In spite of the emerging importance of $S$. canis as a health hazard, little is known about its molecular pathogenesis. Many Gram-positive pathogens which can cause invasive diseases in humans exploit the host proteins to invade and disseminate in tissues [6]. The exclusively human pathogenic bacterium, Streptococcus pyogenes, uses the host fibrinolytic system and interacts with plasminogen [7]. Plasminogen is 
the $92 \mathrm{kDa}$ single-chained pro-enzyme of the broad spectrum serine protease plasmin. It comprises a pre-activation peptide of $\sim 8 \mathrm{kDa}$, five homologous disulfide-bonded triple-loop kringle structures $(\mathrm{K} 1-5 ; 65 \mathrm{kDa})$, and a serineprotease domain $(25 \mathrm{kDa})$ [8]. Plasminogen is cleaved by leukocyte elastase activity into miniplasminogen comprising $\mathrm{K} 5$ and the catalytic domain $\left(\mathrm{Val}_{442}-\mathrm{Asn}_{790}\right)$ [9]. Conversion of the single-chained pro-enzyme to active plasmin is mediated by proteolytic activation via the mammalian plasminogen activators, tissue-type plasminogen activator (tPA), and urokinase (uPA) [10]. Plasmin is involved in intravascular fibrinolysis [11], degradation of extracellular matrix (ECM) material, and is relevant for cell invasion [12]. The capability of bacteria to bind and activate plasminogen to plasmin represents, thereby, a mechanism to invade and disseminate the host. One of the major plasminogen binding components of $S$. pyogenes is the M-like protein PAM which mediates high-affinity binding to $\mathrm{K} 2[13,14]$.

This study describes the identification of a novel M-like protein from $S$. canis, designated SCM that binds plasminogen. The detailed molecular characterization indicated a specific interaction of SCM with the C-terminal part of plasminogen comprising mini-plasminogen. This kind of interaction may represent a novel mechanism for plasminogen interaction different from PAM and other plasminogen binding components of streptococci. Furthermore, the plasminogen activation and the recruitment of plasmin on the bacterial surface of SCM-expressing S. canis led to the degradation and dissolution of fibrin thrombi, indicating a contribution of plasminogenbinding to bacterial dissemination within the host.

\section{EXPERIMENTAL}

\section{Bacterial strains, media and growth conditions}

The strains of $\beta$-haemolytic Group A, C, and G streptococci used in this study are listed in table 1. Bacteria were routinely cultivated in tryptic soy broth (TSB) at $37^{\circ} \mathrm{C}$ without shaking. Escherichia coli were grown in Luria Bertani medium. If indicated, antibiotics were added at following concentrations: ampicillin (100 $\left.\mu \mathrm{g} \cdot \mathrm{ml}^{-1}\right)$, kanamycin $\left(25 \mu \mathrm{g} \cdot \mathrm{ml}^{-1}\right)$.

\section{Proteins and sera}

Human plasminogen (Sigma), kringle domains 1-3 (K1-3, Sigma), and angiostatin (K1-4, Hemochrom Diagnostica) were purchased commercially. Blood plasma from pig, goat, cat, and dog was collected at the Veterinary School Hannover; K4 and mini-plasminogen were prepared as previously described [15]. Plasminogen-specific antibodies and horse raddish peroxidase-conjugated anti-goat and anti-mouse secondary antibodies were purchased from Dako. Purified His-tagged SCM was used to raise polyclonal antibodies in $\mathrm{BALB} / \mathrm{C}$ mice according to standard protocol. Preimmune serum was collected before immunization.

\section{Expression cloning and recombinant DNA techniques}

If not stated otherwise, all enzymes were obtained from NEW ENGLAND BIOLABS (NEB). SCM was amplified from the $S$. canis G361 genome using the primer pair MF-1/MF-2 (GGG GGA TTC AAC AGA GTT ACT GAG GCC AGA GC/ CCC GTC GAC TGC TGT GAA GAA TGG GTT GG), incorporating a BamHI and a SalI restriction site, respectively. Subsequent enzymatic restriction and ligation into the BamHI/SalI digested $p Q E 30$ vector (Qiagen) resulted in the plasmid $p Q E 30-S C M$. The integrity of insert DNA was verified by sequence analysis using ABI Prism dye terminator cycle sequencing (Perkin-Elmer). The N-terminal part of SCM (SCM 25KD) was amplified with the primer pair MF-1/Sal_fog-Sregion (GGG GGA TTC AAC AGA GTT ACT GAG GCC AGA GC/ GCT GTC GAC TTA 
TTA TGC TTT GTC GCT TGC TAA TTG TTC) and sublconed as a BamHI/SalI fragment into $p Q E 30$. Sequence analysis revealed SCM $25 \mathrm{KD}$ as the $\mathrm{N}$-terminal part comprising amino acids 37 to 248 .

Recombinant proteins were obtained by chromatography under native conditions on $\mathrm{Ni}$ nitrilotriacetic acid resins according to the manufacturer's protocols (Qiagen).

Amplification of the SCM protein from different $S$. canis strains was performed using the primer pair all-canis_fwd/all-canis_rev (TAG CGT TGG AAC AGC ATC AC/ $\overline{\mathrm{CTG}}$ CCT CTG CTT TTG CTT TC).

\section{Circular Dichroism spectroscopy}

CD spectra were recorded with a Jasco-J-815 spectrometer using a quartz cell of $1-\mathrm{cm}$ optical path-length, an instrument scanning speed of $100 \mathrm{~nm} / \mathrm{min}$ and over a wavelength range of 195 $\mathrm{nm}-260 \mathrm{~nm}$ at $20^{\circ} \mathrm{C}$. The reported $\mathrm{CD}$ spectrum of each sample represents the average of 10 scans taken at $20^{\circ} \mathrm{C}$. PBS was used as a blank. The helical content of the protein was calculated using the Jasco software.

\section{Heterologous expression of SCM protein S. gordonii strains}

S. gordonii heterologously expressing SCM on its surface was generated using the mutagenesis system of Oggioni and Pozzi [16]. Full-length SCM was amplified from the $S$. canis G361 genome as described above and cloned into the integration vector $p S M B 103$. Transformation of the plasmid in competent $S$. gordonii GP1221 was performed as described by Talay et al. [17].

\section{Binding experiments and competitive inhibition assay}

Purified plasminogen (Sigma) was radiolabelled with ${ }^{125}$ Iodine by a standard chloramine $\mathrm{T}$ method [18], and binding experiments with $\left[{ }^{125} \mathrm{I}\right]$-plasminogen were performed as described previously [19]. Briefly, $2.5 \times 10^{8}$ bacteria were incubated with $20 \mathrm{nCi}$ of iodinated plasminogen or iodinated K1-3. Bacteria were sedimented and bacteria-bound radioactivity was measured using a gamma counter (Packard). In competitive inhibition assays, binding to viable streptococci was measured in the presence of increasing molar excesses of glu-plasminogen (Sigma), the lysine amino acid analogue epsilon-amino caproic acid (6-AHA; Merck), or K1-3 (Sigma). For dot blot experiments, purified SCM and SCM $25 \mathrm{KD}$, respectively, were spotted onto a nitrocellulose membrane (Biorad). Blocking was performed in the presence of $5 \%$ skimmed milk for $2 \mathrm{~h}$ at room temperature. Hybridization with $\left[{ }^{125} \mathrm{I}\right]-$ plasminogen was carried out for $4 \mathrm{~h}$. Binding was detected using X-ray films (Kodak).

\section{Surface plasmon resonance}

The association and dissociation reactions of glu-plasminogen (Sigma) and mini-plasminogen to recombinant SCM and its N-terminal derivative, respectively, were analysed in the BIAcore optical biosensor (BIAcore 2000 system) using CM 5 sensor chips. Covalent immobilization of plasminogen and miniplasminogen was performed by standard amine coupling procedure essentially as described [20]. Additionally, SCM was immobilized on the Chip surface and plasminogen or miniplasminogen, respectively, was used as analytes. Binding analysis was performed in HBS BIAcore running buffer $(10 \mathrm{mM}$ HEPES 150 $\mathrm{mM} \mathrm{NaCl}, 1.4 \mathrm{mM}$ EDTA, $0.05 \%$ Tween-20, $\mathrm{pH} 7.4$ ) at $20^{\circ} \mathrm{C}$ using a flow rate of $30 \mu 1 \cdot \mathrm{min}^{-1}$ in all experiments. The affinity surface was regenerated with $10 \mu \mathrm{l}$ of $20 \mathrm{mM} \mathrm{NaOH}$. Binding was assayed at least in duplicate using independently prepared sensor chips.

\section{Analysis of BIAcore sensogram data}

The interaction kinetics were analyzed from raw data of the BIAcore sensograms suitable for analysis using the kinetic models included in the BIAevaluation software version 3.0. The experimental data were fitted globally by using the simple one-step bimolecular association 
reaction (1:1 Langmuir kinetic: $\mathrm{A}+\mathrm{B} \leftrightarrow \mathrm{AB})$. For each evaluation, a minimum of four data sets were analyzed.

\section{Plasma absorption, Westernblot and immunoblot analysis}

Plasma proteins were eluted from streptococcal surface using $10 \mathrm{mM}$ glycine $\mathrm{pH}$ 2.0. After neutralization with $2 \mathrm{~N} \mathrm{NaOH}$, proteins were subjected to SDS-PAGE with $12 \%$ gels according to the method described by Laemmli [21] and either stained with Coomassie brilliant blue or subsequently transferred to a nitrocellulose membrane (Biorad) using a semidry blotting system. In immunoblots, plasminogen binding was detected by incubation of the membrane with monoclonal antibodies directed against human plasminogen (1:300, American Diagnostica), followed by a secondary antibody coupled to HRP. Peroxidase activity was detected by chemoluminescence using $100 \mathrm{mM}$ Tris $\mathrm{HCl}, 1.25 \mathrm{mM}$ 3aminopthalhydrazide, $225 \mu \mathrm{M}$ p-coumaric acid, $0.01 \% \mathrm{H}_{2} \mathrm{O}_{2}$ at a $\mathrm{pH} 8.8$ in water and exposed to chemoluminescence films (GE Healthcare).

For immunoblot analysis, human plasminogen and its fragments $\mathrm{K} 1-3, \mathrm{~K} 4, \mathrm{~K} 1-4$, and miniplasminogen (mPLG) were spotted onto a nitrocellulose membrane at indicated amounts. Membranes were blocked as described above and incubated with $100 \mu \mathrm{g}$ purified SCM over night at $4^{\circ} \mathrm{C}$. Immunoblot analysis with anti-Mprotein $(1: 200)$ antiserum was performed using HRP-conjugated second antibodies (1:3000) followed by incubation with the substrate solution containing $1 \mathrm{mg} \cdot \mathrm{ml}^{-1}$ 4-chloro-1naphthol and $0.1 \% \mathrm{H}_{2} \mathrm{O}_{2}$ in PBS.

\section{Plasmin activity assay}

Activation of plasmin was monitored in 96 microtiter plates. For detection of secreted streptokinase activity, $150 \mu \mathrm{l}$ of a $50 \mathrm{ml}$ overnight culture were incubated with the same volume of canine or human plasma, respectively, for $30 \mathrm{~min}$ at $37^{\circ} \mathrm{C}$. The chromogenic substrate D-valyl-leucyl-lysine-pnitroanilide dihydrochloride (S-2251, Fluka) was added to a final concentration of $400 \mu \mathrm{M}$. Proteolytic cleavage was detected photometrically at $405 \mathrm{~nm}$ using an ELISA reader (Tecan Sunrise) following time course of 120 min. For detection of cell bound streptokinase activity, $S$. canis bacteria $\left(10^{9}\right.$ $\left.\mathrm{cfu} \cdot \mathrm{ml}^{-1}\right)$ were preincubated with $40 \mu \mathrm{g} \cdot \mathrm{ml}^{-1}$ plasminogen in PBS for $15 \mathrm{~min}$ at $37^{\circ} \mathrm{C}$. After removal of unbound plasminogen by washing, urokinase $(500 \mathrm{ng})$ was added. Plasmin activation was also measured in the presence of $2 \mathrm{U}$ plasmin inhibitor aprotinin or the lysine analogue 6-amino hexanoic acid (6-AHA, Sigma) in concentrations of 2,40 and $80 \mu \mathrm{M}$. Plasminogen-incubated streptococci without activator and non-treated bacteria were used as controls. For analysis of plasmin activation time of surface-bound versus soluble plasminogen, SCM-expressing SGO bacteria were treated essentially as described for radioactive binding assays. Briefly, streptococci were incubated with $55 \mathrm{ng}$ plasminogen for $1 \mathrm{~h}$ at room temperature. Then, cells were washed with PBS and $50 \mathrm{ng}$ uPA was added. The amount of soluble plasminogen was calculated from binding experiments as $80 \%$ of the iodinated protein. Conversion to plasmin was determined as described above.

\section{Degradation of fibrinogen}

S. canis G361 bacteria were preincubated with plasminogen as described, and $5 \times 10^{7}$ cells were incubated with $4 \mu \mathrm{g}$ of plasminogendepleted human fibrinogen (Sigma) following a time series of $5,10,15,20,30$, and $60 \mathrm{~min}$ at $37^{\circ} \mathrm{C}$. Degradation was monitored in the presence of uPA $(500 \mathrm{ng})$ and the reaction was stopped with $50 \mu 1$ of SDS-containing sample buffer. Bacteria were sedimented and samples were separated by SDS-PAGE followed by transfer of proteins to polyvinylidene difluoride membrane (PVDF; Immobilon-P, Millipore) using a semi-dry blotting system. The membranes were blocked as described earlier 
prior to incubation with rabbit antiserum directed against human fibrinogen (Dakopatts, 1:2000). Detection of fibrinogen peptides was carried out using HRP-conjugated anti-rabbit antibodies (1:3000) and chemiluminescence as described above.

\section{Degradation of fibrin and transmigration of S. canis through fibrin}

Fibrin matrix was produced on cover slips and transwell cell culture inserts (polycarbonate membranes with $3.0 \mu \mathrm{m}$ pore size; Costar) by incubating $100 \mu \mathrm{l}$ of $50 \mathrm{mg} \cdot \mathrm{ml}^{-1}$ plasminogendepleted human fibrinogen (Millipore) in PBS with $2 \mu 1$ of $1.0 \mathrm{KU} \cdot \mathrm{ml}^{-1}$ thrombin (from bovine plasma, MP Biomedicals) for $10 \mathrm{~h}$ at $37^{\circ} \mathrm{C}$. S. canis G361 pretreated with plasminogen as described, was applied with a dose of $1 \times 10^{7}$ in $200 \mu 1$ PBS to the fibrin matrix. Surface-bound plasminogen was activated with uPA (500 ng). Bacterial transmigration from the upper to the lower chamber was quantified by plating serial dilutions of the lower chamber solution on blood agar plates. Experiments were carried out for up to $6 \mathrm{~h}$ and samples were plated in intervals of $120 \mathrm{~min}$. Data represent the means \pm SD of one experiment performed in triplicate. Experiments were repeated three times.

\section{Time-lapse microscopy}

Fibrin clots were generated in $\mu$-Slides $(\mu$-Slide 8 well, Ibidi, Munich, Germany) as described above. One x $10^{7}$ bacteria were added per well and samples were mounted on an inverted microscope (Axio Observer.Z1) equipped with a $25 \times / 0.8$ NA LCI Plan-Neofluar objective driven by AxioVision Software 4.7 (Zeiss, Jena, Germany). Time-lapse imaging was performed at $37^{\circ} \mathrm{C}$ and frames were taken every two minutes. Video frames were processed for contrast and brightness using Fiji/ImageJ.

\section{Electron microscopy}

Samples were fixed in 5\% formaldehyde and $2 \%$ glutaraldehyde in cacodylate buffer $(0.1 \mathrm{M}$ cacodylate, $0.01 \mathrm{M} \mathrm{CaCl}_{2}, 0.01 \mathrm{M} \mathrm{MgCl}_{2}, 0.09$ $\mathrm{M}$ sucrose, $\mathrm{pH}$ 6.9) for $1 \mathrm{~h}$ on ice and washed with TE-buffer $(20 \mathrm{mM}$ TRIS, $1 \mathrm{mM}$ EDTA, $\mathrm{pH}$ 7.0) before dehydrating in a graded series of acetone $(10,30,50,70,90,100 \%)$ on ice for 15 min for each step. Samples were then subjected to critical-point drying with liquid $\mathrm{CO}_{2}(\mathrm{CPD}$ 30, Bal-Tec, Liechtenstein). Dried samples were covered with a gold film by sputter coating (SCD 500, Bal-Tec, Liechtenstein) before examination in a field emission scanning electron microscope Zeiss DSM 982 Gemini (Zeiss, Germany) using the Everhart Thornley SE detector and the SE-inlens detector in a $50: 50$ ratio with an acceleration voltage of $5 \mathrm{kV}$. Images were recorded onto a MO-disk, contrast and brightness was adjusted applying Adobe Photoshop CS3.

\section{Computational analysis}

Prediction of Gram-positive signal sequences was carried out using the SignalP program (http://www.cbs.dtu.dk/services/SignalP).

Prediction of fibrillar structure was performed in silico using the coiled-coil program (http://www.ch.embnet.org/software/COILS).

\section{RESULTS}

\section{Plasminogen binding to Group C and G streptococci}

During the course of wound infection, streptococci encounter different components from host blood and tissue. Recruitment of human plasma components to bacterial S. canis isolates G1, G2, G14, G361 and S. equisimilis C90 has been analysed after plasma incubation. Coomassie stain detected the presence of a 90 $\mathrm{kDa}$ protein after elution of surface-bound plasma proteins from G361, C90, and to a lesser extent, G1 (Fig. 1A, black arrow). Immunoblot analysis with antibodies directed against plasminogen identified the respective protein as human plasminogen (Fig. 1B). In addition, $S$. 
canis isolate G361 can also recruite plasminogen from plasma derived from different mammalian species including pig, goat, cat, and dog (Fig. 1C, black arrow). In radioactive interaction studies binding of iodinated human plasminogen, was detected for S. canis isolates $\mathrm{G} 1, \mathrm{G} 8, \mathrm{G} 13, \mathrm{G} 15$, and $\mathrm{G} 361$ ranging from $16 \%$ binding for strain G8 up to $60 \%$ for S. canis G361 (Fig. 1D). Comparative plasminogen binding activity was determined for PAM-expressing S. pyogenes A158 (data not shown), whereas only marginal plasminogen binding has been observed for the isolates G2, G14, and G17 (Fig. 1D). These results demonstrate a specific interaction of zoonotic $S$. canis isolates with human plasminogen and a non-species specific recruitment of plasminogen from plasma on the $S$. canis cell surface.

\section{Identification of SCM as a M-like protein of S. canis (SCM) mediating plasminogen binding}

M- and M-like proteins of human group $\mathrm{A}, \mathrm{C}$ and $\mathrm{G}$ streptococci have been identified as plasminogen receptors [22]. Based on a DNA sequence, that has been supposed to encode a M-like protein of $S$. canis (accession number: FJ594772) and an ongoing genome sequencing project, the respective gene was amplified from the genome of strain G361 and termed SCM. The amino acid sequence of the purified Histagged protein elucidates a $\mathrm{N}$-terminal signal sequence with a predicted cleavage site between alanine and glutamic acid (VKA-EH) and a LPxTG motif for sortase-mediated covalent cell wall attachment at the C-terminus (Fig. 2A). Using the prediction program COILS a probability for coiled-coil formation of more than $90 \%$ was calculated for amino acids 109 to 360 of full length SCM. In further studies, CD spectroscopy revealed a typical curve progression for alpha-helical proteins with two minima at 208 and $222 \mathrm{~nm}$, respectively. The helical content was estimated as $72.4 \%$. Furthermore, a 222:208 nm ratio of 1.13 was calculated (Fig. 2B). Since this ratio is $\geq 1$ for coiled-coil proteins $[23,24]$, these data suggest a dimeric form of SCM under physiological conditions. In addition, a typical feature of coiled-coil proteins is a repeating heptad of the generalized sequence $a-b-c-d-e-f-g$, whereas positions a and $\mathrm{d}$ are occupied by hydrophobic residues [25]. An alignment with other $\mathrm{M}$ - and M-like proteins elucidated the presence of the hydrophobic amino acids in the positions a and $\mathrm{d}$ also within the SCM sequence (Fig. 2C). Furthermore, sequence alterations occur as deletion of seven amino acids supporting the coiled-coil structure of SCM.

In order to detect scm in the genome of different S. canis isolates, a specific PCR with oligonucleotides based on the $\mathrm{N}$-terminal signal sequence and the conserved C-terminal LPxTG motif has been established (Fig. 2D). Sequence analysis revealed that the scm fragment is not ubiquitously present in all S. canis isolates (Fig. 2D). The scm gene could be detected in the genomes of strains G1, G8, G13, G15 and G361. Within these strains, presence of scm correlates with a high plasminogen binding capacity (Fig. 1D). In contrast, no amplification of scm was observed for the S. canis strains G2, G14 and G17 which correlates with only a weak plasminogen binding capacity (Fig. 2D). A total number of 19 strains have been tested and all strains showing strong plasminogen binding were also positive for scm (Fig. 2D). These results indicated that $\mathrm{SCM}$ is necessary for plasminogen binding in S. canis.

\section{Biochemical analyses of plasminogen binding to SCM}

SCM was heterologously expressed in the nonplasminogen binding $S$. gordonii. In contrast to the wild type strain (SGO WT), the SCM expressing $S$. gordonii strain (SGO SCM) showed strong binding to iodinated human plasminogen (Fig. 3A). Results of dot blot overlay analyses confirmed the recombinant purified SCM as plasminogen-binding protein of $S$. canis. Furthermore, the plasminogen binding domain of SCM could be narrowed 
down to the first 214 amino acids of the mature protein representing SCM 25KD (Fig. 3B). Surface plasmon resonance analysis was performed by using plasminogen as immobilized ligand and purified SCM and SCM $25 \mathrm{KD}$ as analytes in a series of concentrations $(0.125 \mu \mathrm{M}-4 \mu \mathrm{M})$. Sensogram data of SCM binding to immobilized plasminogen revealed a specific and concentration-dependent binding interaction (Fig. 3C). Evaluation of the binding data determined dissociation constants of $2.69 \mathrm{x}$ $10^{-8} \mathrm{M}$ for the plasminogen interaction with SCM (Fig. 3C) and $2.07 \times 10^{-8} \mathrm{M}$ for the Nterminal part of SCM (Fig. 3D). Dissociation constants within the same range $\left(5.10 \times 10^{-7} \mathrm{M}\right)$ could also be confirmed in kinetic analysis with $\mathrm{SCM}$ as immobilized ligand and plasminogen as analyte in solution (Fig. 3E). A summary of the BIAcore results representing the association rate constant $\left(\mathrm{k}_{\mathrm{a}}\right)$, the dissociation rate constant $\left(\mathrm{k}_{\mathrm{d}}\right)$, the affinity constant $\left(\mathrm{K}_{\mathrm{D}}\right)$, and the chi square values $\left(\chi^{2}\right)$ were depicted in Table 2 .

\section{Characterization of SCM-binding domain in human plasminogen}

Kringle domains of plasminogen are well known binding sites for a variety of bacterial plasminogen receptors containing exposed lysine residues [26, 27]. In order to characterize the region of interaction between SCM and the plasminogen molecule to detail, different inhibition studies were performed in radioactive binding experiments. A dose-dependent inhibition of plasminogen binding to the surface of $S$. canis G361 was observed in the presence of increasing amounts of 6-AHA (Fig. 4A). Addition of $300 \mathrm{mM} \mathrm{6-AHA} \mathrm{led} \mathrm{to} \mathrm{a} \mathrm{residual}$ binding capacity of $25.4 \%$. A dose-dependent inhibition of plasminogen binding from $66.5 \%$ with $62.5 \mathrm{nM}$ inhibitor to $19.2 \%$ with $2 \mu \mathrm{M}$ of non-labelled plasminogen underlined the specificity of the interaction (Fig. 4B). In contrast, no difference in plasminogen binding capacity was observed in the presence of $2 \mu \mathrm{M}$ non-labelled K1-3 (Fig. 4B). PAM expressing $S$. pyogenes strain A158 bound to K1-3 with a capacity of $58.0 \%$ (Fig. 4D), which was inhibited by the addition of $2 \mu \mathrm{M}$ non-labelled plasminogen and $2 \mu \mathrm{M} \mathrm{K1-3} \mathrm{(Fig.} \mathrm{4C).} \mathrm{These}$ results were supported by the fact that neither $S$. canis strain G361 (7.6\%) nor the SCM expressing S. gordonii strain SGO SCM (2.8\%) were able to bind to iodinated K1-3 (Fig. 4D). For mapping the binding site on plasminogen, dot blot experiments using different fragments of the entire plasminogen molecule and recombinant SCM was performed. Fig. 4E showed a specific, dose-dependent binding signal of SCM only to fuil length plasminogen and to the C-terminal elastase-digested product mini-plasminogen, whereas no interaction could be detected using the fragments K1-3, K1-4, and K4, respectively. Surface plasmon resonance analyses of binding kinetics with immobilised mini-plasminogen and SCM as analyte revealed a high dissociation constant of $1.38 \times 10^{-8} \mathrm{M}$ which is within the same high affinity range as determined for the kinetics between SCM and plasminogen (Fig. 4F, Table 2).

\section{Activation of plasminogen and recruitment of plasmin on $S$. canis cell surface}

Activation of plasminogen to proteolytic active plasmin was determined by photometrical measurement of the plasmin specific chromogenic substrate S-2251 (Fig. 5A). No plasmin activity was detected in the supernatant of the zoonotic isolate G361 with both, human or canine plasma (Fig. 5A, B). In contrast, the $S$. equisimilis strain C90 recruited plasminogen from human plasma (shown in Fig. 1B) and converted human plasminogen but not canineplasma derived plasminogen into plasmin (Fig. $5 \mathrm{~A}, \mathrm{~B})$. These results indicate that no endogenous plasminogen activator like streptokinase is expressed in S. canis, and also emphasize the species-specific activity of streptokinase derived from S. equisimilis [28]. Interestingly, human plasminogen bound to the surface of S. canis G361 was activated in a time dependent manner in the presence of the 
eukaryotic activator urokinase (Fig. 5C), whereas no plasmin activity was detected in the absence of plasminogen or of plasminogen activators (Fig. 5C). The serine protease inhibitor aprotinin inhibits plasminogen activation on the bacterial surface, indicating the serine protease specificity of plasminmediated substrate conversion (Fig. 5C). Plasmin activity was also significantly reduced in the presence of 2,40 , and $80 \mathrm{mM} 6$-AHA, in a dose-dependent manner (Fig. 5D). In addition to the results obtained from binding analyses, the inhibitory activity of 6-AHA for plasminogen activation confirmed, that the lysine binding sites within plasminogen kringle domains are involved in interaction of SCM with plasminogen. Interestingly, plasminogen bound to SCM-expressing SGO underwent a faster conversion into plasmin by urokinase as compared to soluble plasminogen (Fig. 5E). These results indicate that binding of plasminogen to SCM on bacterial surface accelerates the rate of plasmin formation.

\section{Binding of SCM protein to plasminogen promotes degradation of fibrinogen and fibrin and transmigration of streptococci through microthrombi}

Fibrinogen is the major component of fibrin clots generated in response to vessel injuries and inflammatory processes. Immunoblot analysis of fibrinogen degradation detected a time-dependent degradation of purified human fibrinogen by plasminogen-coated $S$. canis bacteria in the presence of urokinase (Fig. 6A). Degradation products of fibrinogen fragments were produced after $5 \mathrm{~min}$ of incubation with bacteria and fragmentation was enhanced following a time series up to $60 \mathrm{~min}$. In contrast, no degradation was detected by plasminogen-coated S. canis bacteria without any activator (Fig. 6A lane 2). In order to analyse fibrinolytic activity by plasminogencoated bacteria, fibrin clots were generated on glass cover slips by thrombin incubation of plasminogen-depleted fibrinogen. Photographic visualization of the fibrin clots demonstrated that the white and turbid microthrombi were totally dissolved into a clear solution by plasminogen-coated $S$. canis G361 in the presence of urokinase within $4 \mathrm{~h}$ of incubation (Fig. 6B). No dissolution of the fibrin clots could be observed after incubation with bacteria or plasminogen-coated bacteria without activator (Fig. 6B), indicating that the fibrin thrombi represent a tight but protease-sensitive barrier. Plasmin-mediated transmigration activity of $S$. canis bacteria through fibrin clots generated on membranes of transwell cell culture inserts was determined by plating of diluted aliquots from the lower well (Fig. 6B, table). Transmigration of $3.7( \pm 0.7) \times 10^{6}$ $\mathrm{cfu} \cdot \mathrm{ml}^{-1} \mathrm{~S}$. canis bacteria was detected after $4 \mathrm{~h}$ and $8.3( \pm 0.8) \times 10^{6} \mathrm{cfu} \cdot \mathrm{ml}^{-1}$ bacteria after $6 \mathrm{~h}$ of incubation of thrombi with plasmin-coated bacteria. Dissolution of fibrin bundles by plasmin-coated $S$. canis bacteria was also visualized by time lapse microscopy. The timedependent fibrin degradation is shown in Fig. 6C illustrating the dynamics of plasminmediated fibrin degradation.

\section{Electron microscopic visualization of fibrin degradation by $S$. canis and SCM-expressing S. gordonii}

Electron microscopic studies illustrated the dissolution of the fibrin bundles of $S$. canis G361 (Fig. 7A-H). Fibrin fibres of a generated fibrinogen thrombus were microscopically visualized as ordered, cable-like structures of up to $0.35 \mu \mathrm{m}$ in diameter (Fig. 7A, B). Without plasmin-mediated fibrinogen degradation, the cell chains of $S$. canis bacteria showed strong adherence to the fibrin surface layer (Fig. 7C) and also to the non-dissolved fibrin fibrils (Fig. $7 \mathrm{D}, \mathrm{E})$. The fibrin bundle structure remained unchanged after incubation with plasminogencoated bacteria in the absence of a plasminogen activator (Fig. 7E). Fibrin fibres were substantially degraded after incubation of thrombi with plasminogen-pretreated bacteria in the presence of urokinase (Fig. 7F-H). Higher 
magnifications visualized, that the bacteriabound proteolytic activity resulted in an enhanced dissolution of the fibrin matrix forming a halo of dissolved fibrin around the bacteria and led the bacteria sink into the underlying fibrin layer (Fig. $7 \mathrm{G}$ and $\mathrm{H}$ ). Plasmin-mediated fibrin degradation was also analysed by electron microscopy after incubation of the microthrombi with S. gordonii bacteria expressing SCM (Fig. 7I-P). No fibrin degradation was detected by $S$. gordonii bacteria (Fig. 7I) or plasminogen-preincubated S. gordonii (Fig. 7J) which lack SCM on its surface (SGO WT). Moreover, no dissolution of the fibrin bundles was observed by plasminogen preincubated S. gordonii (SGO WT) bacteria in the presence of the plasminogen activator urokinase (Fig. $7 \mathrm{~K}, \mathrm{~L}$ ). Similar to $S$. canis, $S$. gordonii bacteria expressing SCM on the surface (SGO SCM) show no fibrin degradation activity but strong adherence to the fibrin matrix (Fig. 7M, N). Moreover, in conjunction to $S$. canis, dissolution of the ordered fibrin structures was only detected by plasminencoated S. gordonii-expressing SCM (Fig. 70 and $\mathrm{P}$ ). In conclusion, the degradation analyses indicate that plasmin-mediated dissolution of soluble fibrinogen and fibrinous thrombi represents a key function of the $S$. canis M-like protein for streptococcal transmigration and dissolution of the fibrin matrix.

\section{DISCUSSION}

S. canis is well known as an emerging infective agent responsible for a variety of invasive diseases in domestic animals [2] as well as humans [3-5]. Despite its zoonotic potential, the knowledge about virulence mechanisms required for establishing a $S$. canis infection remained mostly elusive. The subversion of host-derived proteolytic activity for invasive and degradative dissemination within the host tissue belongs to one of the most important pathogenicity mechanisms described for pathogenic bacteria so far [6]. Several bacterial plasminogen binding proteins have been identified up to now, but the pathophysiological role of plasminogen binding to zoonotic streptococci like $S$. canis has not been investigated in detail. The presented study revealed the presence of a novel plasminogen receptor (SCM) on the surface of $S$. canis. Detailed biochemical analysis characterized $\mathrm{SCM}$ as a high-affinity ligand of the elastasedigested plasminogen fragment miniplasminogen. Despite the lack of endogenous streptokinase activity, surface-bound plasminogen is convertible to plasmin by host-derived plasminogen activators, which enables $S$. canis to degrade ECM matrix molecules and dissolve aggregated fibrin thrombi. The use of plasmin might therefore represent an important virulence trait for establishing a $S$. canis infection.

$S$. canis is mostly isolated from animals, in particular, from dogs, cats, and cows [1]. A close genetic relationship and a similar clinical phenotype to other group A, C, and G streptococci, lead to inclusion of $S$. canis in the pyogenic group of streptococci [29]. It has been described for the species S. pyogenes (group A streptococci, GAS) and S. dysgalactiae sub. equisimilis (group C and G streptococci, GCGS) that their ability to bind and activate plasminogen has an outstanding role in pathogenicity [30, 31]. Receptors for plasminogen binding on the streptococcal surface are M- and M-like proteins like PAM, GCS3, and MLG72 [13, 31]. M proteins form fibrillar structures on the surface of streptococci which have been characterized extensively as important virulence factors in the pathogenesis of GAS and GCGS infections [32, 33]. Usually, emm genes are detectable by specific oligonucleotides. S. canis is characterized as emm-negative in the established PCR-test described by the Centre of Disease Control (CDC) for emm typing. One exception is published by Ahmad and colleagues [34]. Very recently, Yang and coworkers identified a protein of $S$. canis (SPASc) showing similarity to the protective antigen $\mathrm{SpaZ}$ of $S$. equi sub. zooepidemicus, SPA of S. pyogenes, and SeM, the M-like protein of Streptococcus equi [35]. An orthologue of SPASc was recombinantly 
expressed as a His-tag fusion. CD spectroscopy demonstrated an alpha-helical structure and a high probability for dimerization under physiological conditions. The formation of a coiled-coil structure is supported by the fact that an alignment of the amino acid sequence with known $\mathrm{M}$ - and M-like proteins revealed the generalized heptad sequence characteristic for alpha-helical coiled-coil proteins. In summary, structural properties, binding of ECM proteins and sequence homologies characterize SCM as an M-like protein of S. canis.

Dot blot overlay assays showed a concentrationdependent binding of SCM to iodinated plasminogen. The quality of SCM mediated plasminogen binding was supported by the determination of a dissociation constant within the nanomolar range by surface plasmon resonance studies. Furthermore, strong plasminogen binding activity of heterologously SCM-expressing S. gordonii bacteria also confirmed the high relevance of SCM for plasminogen interaction of S. canis.

The PAM-binding site has been identified within the kringle domain 2 of plasminogen [36, 37]. Kringle domains have been shown to participate in high affinity binding interactions with streptokinase and also mediate interaction of plasminogen with plasminogen activators, plasmin substrates, fibrin, and cell surface receptors $[38,39]$. In contrast to PAM, binding analysis revealed that SCM shows no interaction with the first four kringle domains of plasminogen. Moreover, to the best of our knowledge, SCM is the first bacterial plasminogen binding protein interacting in lysine dependent manner with the C-terminal part of plasminogen, termed mini-plasminogen. Surface plasmon resonance studies confirmed the interaction of SCM with mini-plasminogen reaching $\mathrm{kD}$ values within nanomolar range. This kind of interaction has only been suggested for the plasminogen interaction with $H$. pylori [40], Trypanosoma cruzi epimastigotes, and streptococci from bovine origin [41, 42]. Several reports describe an interaction of plasminogen binding proteins with the lysine binding sites present in the $\mathrm{N}$-terminal kringle domains of plasminogen. Since we demonstrate an interaction of SCM with the C-terminal part of plasminogen, composed of kringle domain 5 and the catalytic domain, the different interaction sites may also contribute to a different mechanism of host-pathogen interaction. Detection of mini-plasminogen was associated with low levels of plasminogen and high levels of elastase-al protease inhibitor complex in patients suffering from septicemia $[43,44]$ and is also able to produce clot lysis after activation with IPA in plasminogendepleted plasma [9]. Therefore, interaction of pathogenic $S$. canis with mini-plasminogen may enable the streptococci to recruit plasmin activity after binding of plasminogen or miniplasminogen present under different pathophysiological conditions. The inhibition of plasminogen binding by the lysine analogue 6AHA is often interpreted as identification of lysine binding sites of kringle domains as major interaction sites [13, 45, 46]. Plasminogen binding of SCM as well as conversion of plasminogen to proteolytic active plasmin on the $S$. canis surface was inhibited in concentration-dependent manner by 6-AHA. These results would support an interaction of SCM with the lysine binding site present in kringle domain 5 of mini-plasminogen. In contrast to SCM, group A streptococcal PAM has been shown to bind to the $\mathrm{K} 2$ of plasminogen, which exhibits a low affinity lysine binding site [36]. X-ray analysis of the PAM-kringle-2 protein complex revealed that a "pseudo-lysine" like binding is formed in PAM by positively and negatively charged amino acids within the plasminogen binding region of PAM [37]. This kind of pseudo-lysine interaction has also been proposed for binding of lysine analogues to K1 and K5 [37]. The detailed characterization of specific amino acids involved in interaction of SCM with miniplasminogen is currently in progress and will elucidate the role of lysine residues in binding of SCM to mini-plasminogen. 
Immobilization of plasminogen on physiological fibrin surfaces or on cell surface of bacteria has been shown to accelerate conversion into proteolytic active plasmin by eukaryotic activators like tissue-type activator or urokinase type plasminogen activator, respectively [47]. Plasmin activation measurements confirmed an increase in activation of plasminogen bound to SCM-expressing $S$. gordonii bacteria in contrast to significantly slower plasmin activation in the presence of soluble plasminogen. Accelerated activation was also shown for plasminogen which was bound to surface displayed eukaryotic enolase [26]. In contrast to GAS and GCGS, S. canis is not expressing an endogenous plasminogen activator [31]. Therefore, a host-derived plasminogen activator is required for activation of cell surface bound plasminogen in an aprotinin-sensitive manner. Blood coagulation resulting in fibrinogen-enriched thrombi has been suggested to capture invasive pathogenic microorganisms in order to prevent spreading of bacteria into bloodstream and into deeper tissue sites [36, 48]. Electron microscopic illustration and time-lapse visualization clearly demonstrate the proteolytic degradation activity recruited on the surface of $S$. canis or SCM expressing $S$. gordonii bacteria. Generated fibrin thrombi were completely dissolved by plasmin-encoated bacteria. Therefore, bacteria-bound proteolytic activity enables the bacterial release from the coagulative capture within blood thrombi and presents an effective evasion mechanism for invasive pathogenic bacteria. Moreover, it has been shown, that bacterial-bound plasmin activity is associated with pathological phenotype. In patients with Gram-negative septicemia, high levels of fibrin degradation products have been detected [49] and also, interaction of Group A streptococcal streptokinase with host fibrinolytic system facilitates bacterial access to the vasculature [50]. Interestingly, neonatal septicemia and meningitis, which is a clinical feature of $S$. canis as well as E. coli infections, has also been associated with tPA-catalysed activation of plasminogen bound to E. coli fimbriae [2, 3, 51, 52].

The recruitment of plasminogen to the surface of the invasive zoonotic pathogen $S$. canis might, therefore, represent an important virulence mechanism leading to effective evasion of proteolytic active bacteria from thrombus capture within vasculature of the host and to bacterial dissemination into deeper tissue sites. The elucidation of the interaction mechanism between SCM and mini-plasminogen offers new insights into understanding interaction of M-like proteins with the human fibrinolytic system and enables the development of new intervention therapies.

\section{ACKNOWLEDGEMENTS}

We are grateful to Ina Schleicher, Franziska Voigt, Agnes Zimmer and Nadine Nachtigall for technical assistance. We thank Uwe Schubert, Giessen for the technical support and Dr. Oliver Goldmann for helpful discussion. We also like to thank Prof. J.F. Presocott (Department of Pathobiology, University of Guelph, Ont., Canada), Prof. B.W. Beall (Centers for Disease Control and Prevention, Atlanta, Georgia, USA) and Dr. M. van der Linden (National Reference Centre for Streptococci, Aachen, Germany) for providing strains.

\section{FUNDING}

The research leading to these results has received funding from the European Community's Seventh Framework Programme under Grant Agreement no. HEALTH-F3-2009223111. 


\section{REFERENCES}

Devriese, L. A., Hommez, J., Klipper-Bälz, R. and Schleifer, K.-H. (1986) Streptococcus canis sp. nov.: a Species of Group G Streptococci from Animals. International Journal of Systematic Bacteriology. 36, 422-425

DeWinter, L. M., Low, D. E. and Prescott, J. F. (1999) Virulence of Streptococcus canis from canine streptococcal toxic shock syndrome and necrotizing fasciitis. Vet Microbiol. 70, 95-110

Bert, F. and Lambert-Zechovsky, N. (1997) Septicemia caused by Streptococcus canis in a human. J Clin Microbiol. 35, 777-779

Takeda, N., Kikuchi, K., Asano, R., Harada, T., Totsuka, K., Sumiyoshi, T., Uchiyama, T. and Hosoda, S. (2001) Recurrent septicemia caused by Streptococcus canis after a dog bite. Scand J Infect Dis. 33, 927-928

Whatmore, A. M., Engler, K. H., Gudmundsdottir, G. and Efstratiou, A. (2001) Identification of isolates of Streptococcus canis infecting humans. J Clin Microbiol. 39, 4196-4199

Bergmann, S. and Hammerschmidt, S. (2007) Fibrinolysis and host response in bacterial infections. Thromb Haemost. 98, 512-520

Wang, H., Lottenberg, R. and Boyle, M. D. (1995) Analysis of the interaction of group A streptococci with fibrinogen, streptokinase and plasminogen. Microb Pathog. 18, 153-166

Miyashita, C., Wenzel, E. and Heiden, M. (1988) Plasminogen: a brief introduction into its biochemistry and function. Haemostasis. 18 Suppl 1, 7-13

Duboscq, C., Genoud, V., Parborell, M. F. and Kordich, L. C. (1997) Impaired clot lysis by rt-PA catalyzed miniplasminogen activation. Thromb Res. 86, 505-513

Castellino, F. J. and Powell, J. R. (1981) Human plasminogen. Methods Enzymol. 80 Pt C, 365-378

Collen, D. and Lijnen, H. R. (1994) Staphylokinase, a fibrin-specific plasminogen activator with therapeutic potential? Blood. 84, 680-686

Werb, Z. (1997) ECM and cell surface proteolysis: regulating cellular ecology. Cell. 91, 439-442

Berge, A. and Sjobring, U. (1993) PAM, a novel plasminogen-binding protein from Streptococcus pyogenes. J Biol Chem. 268, 25417-25424

Ringdahl, U., Svensson, M., Wistedt, A. C., Renne, T., Kellner, R., Muller-Esterl, W. and Sjobring, U. (1998) Molecular co-operation between protein PAM and streptokinase for plasmin acquisition by Streptococcus pyogenes. J Biol Chem. 273, 6424-6430

Chavakis, T., Athanasopoulos, A., Rhee, J.S., Orlova, V., Schmidt-Wöll, T., Bierhaus, A., May, A.E., Celik, I., Nawroth, P.P., Preissner, K.T. (2005) Angiostatin is a novel anti-inflammatory factor by inhibiting leukocyte recruitment. Blood 105, 1036-1043

Oggioni, M. R. and Pozzi, G. (1996) A host-vector system for heterologous gene expression in Streptococcus gordonii. Gene. 169, 85-90

Talay, S. R., Zock, A., Rohde, M., Molinari, G., Oggioni, M., Pozzi, G., Guzman, C. A. and Chhatwal, G. S. (2000) Co-operative binding of human fibronectin to $\mathrm{Sfbl}$ protein triggers streptococcal invasion into respiratory epithelial cells. Cell Microbiol. 2, 521-535

Chhatwal, G. S., Preissner, K. T., Muller-Berghaus, G. and Blobel, H. (1987) Specific binding of the human S protein (vitronectin) to streptococci, Staphylococcus aureus, and Escherichia coli. Infect Immun. 55, 1878-1883

Hammerschmidt, S., Talay, S. R., Brandtzaeg, P. and Chhatwal, G. S. (1997) SpsA, a novel pneumococcal surface protein with specific binding to secretory immunoglobulin A and secretory component. Mol Microbiol. 25, 1113-1124

Bergmann, S., Wild, D., Diekmann, O., Frank, R., Bracht, D., Chhatwal, G. S. and Hammerschmidt, S. (2003) Identification of a novel plasmin(ogen)-binding motif in surface displayed alpha-enolase of Streptococcus pneumoniae. Mol Microbiol. 49, 411-423

Laemmli, U. K. (1970) Cleavage of structural proteins during the assembly of the head of bacteriophage T4. Nature. 227, 680-685

Lahteenmaki, K., Kuusela, P. and Korhonen, T. K. (2001) Bacterial plasminogen activators and receptors. FEMS Microbiol Rev. 25, 531-552

Lau, S. Y., Taneja, A. K. and Hodges, R. S. (1984) Synthesis of a model protein of defined secondary and quaternary structure. Effect of chain length on the stabilization and formation of two-stranded alpha-helical coiled-coils. J Biol Chem. 259, 13253-61.

McNamara, C., Zinkernagel, A. S., Macheboeuf, P., Cunningham, M. W., Nizet, V. and Ghosh, P. (2008) Coiledcoil irregularities and instabilities in group A Streptococcus M1 are required for virulence. Science. 319, 1405 1408 
Manjula, B. N., Khandke, K. M., Fairwell, T., Relf, W. A. and Sriprakash, K. S. (1991) Heptad motifs within the distal subdomain of the coiled-coil rod region of $\mathrm{M}$ protein from rheumatic fever and nephritis associated serotypes of group A streptococci are distinct from each other: nucleotide sequence of the M57 gene and relation of the deduced amino acid sequence to other M proteins. J Protein Chem. 10, 369-384

Miles, L. A., Dahlberg, C. M., Plescia, J., Felez, J., Kato, K. and Plow, E. F. (1991) Role of cell-surface lysines in plasminogen binding to cells: identification of alpha-enolase as a candidate plasminogen receptor. Biochemistry. 30, 1682-1691

Redlitz, A. and Plow, E. F. (1995) Receptors for plasminogen and t-PA: an update. Baillieres Clin Haematol. 8, 313-327

Schroeder, B., Boyle, M. D., Sheerin, B. R., Asbury, A. C. and Lottenberg, R. (1999) Species specificity of plasminogen activation and acquisition of surface-associated proteolytic activity by group $\mathrm{C}$ streptococci grown in plasma. Infect Immun. 67, 6487-6495

Kawamura, Y., Hou, X. G., Sultana, F., Miura, H. and Ezaki, T. (1995) Determination of 16S rRNA sequences of Streptococcus mitis and Streptococcus gordonii and phylogenetic relationships among members of the genus Streptococcus. Int J Syst Bacteriol. 45, 406-408

Ben Nasr, A., Wistedt, A., Ringdahl, U. and Sjobring, U. (1994) Streptokinase activates plasminogen bound to human group C and G streptococci through M-like proteins. Eur J Biochem. 222, 267-276

Sun, H., Ringdahl, U., Homeister, J. W., Fay, W. P., Engleberg, N. C., Yang, A. Y., Rozek, L. S., Wang, X., Sjobring, U. and Ginsburg, D. (2004) Plasminogen is a critical host pathogenicity factor for group A streptococcal infection. Science. 305, 1283-1286

Areschoug, T., Carlsson, F., Stalhammar-Carlemalm, M. and Lindahl, G. (2004) Host-pathogen interactions in Streptococcus pyogenes infections, with special reference to puerperal fever and a comment on vaccine development. Vaccine. 22 Suppl 1, S9-S14

Fischetti, V. A. (1991) Streptococcal M protein. Sci Am. 264, 58-65

Ahmad, Y., Gertz, R. E., Jr., Li, Z., Sakota, V., Broyles, L. N., Van Beneden, C., Facklam, R., Shewmaker, P. L., Reingold, A., Farley, M. M. and Beall, B. W. (2009) Genetic relationships deduced from emm and multilocus sequence typing of invasive Streptococcus dysgalactiae subsp. equisimilis and $S$. canis recovered from isolates collected in the United States. J Clin Microbiol. 47, 2046-2054

Yang, J., Liu, Y., Xu, J. and Li, B. Characterization of a new protective antigen of Streptococcus canis. Vet Res Commun. 34, 413-421

Wistedt, A. C., Ringdahl, U., Muller-Esterl, W. and Sjobring, U. (1995) Identification of a plasminogen-binding motif in PAM, a bacterial surface protein. Mol Microbiol. 18, 569-578

Fu, Q., Figuera-Losada, M., Ploplis, V. A., Cnudde, S., Geiger, J. H., Prorok, M. and Castellino, F. J. (2008) The lack of binding of VEK-30, an internal peptide from the group A streptococcal M-like protein, PAM, to murine plasminogen is due to two amino acid replacements in the plasminogen kringle-2 domain. J Biol Chem. 283, $1580-1587$

Castellino, F. J. and McCance, S. G. (1997) The kringle domains of human plasminogen. Ciba Found Symp. 212 , 46-60; discussion 60-45

Mangel, W. F., Lin, B. H. and Ramakrishnan, V. (1990) Characterization of an extremely large, ligand-induced conformational change in plasminogen. Science. 248, 69-73

Ljungh, A. (2000) Helicobacter pylori interactions with plasminogen. Methods. 21, 151-157

Rojas, M., Labrador, I., Concepcion, J. L., Aldana, E. and Avilan, L. (2008) Characteristics of plasminogen binding to Trypanosoma cruzi epimastigotes. Acta Trop. 107, 54-58

Ullberg, M., Karlsson, I., Wiman, B. and Kronvall, G. (1992) Two types of receptors for human plasminogen on group G streptococci. APMIS. 100, 21-28

Kordich, L. C., Porterie, V. P., Lago, O., Bergonzelli, G. E., Sassetti, B. and Sanchez Avalos, J. C. (1987) Miniplasminogen like molecule in septic patients. Thromb Res. 47, 553-560

Machovich, R. and Owen, W. G. (1990) The elastase-mediated pathway of fibrinolysis. Blood Coagul Fibrinolysis. 1, 79-90

Kuusela, P., Ullberg, M., Kronvall, G., Tervo, T., Tarkkanen, A. and Saksela, O. (1992) Surface-associated activation of plasminogen on gram-positive bacteria. Effect of plasmin on the adherence of Staphylococcus aureus. Acta Ophthalmol Suppl, 42-46

Lin, L. F., Houng, A. and Reed, G. L. (2000) Epsilon amino caproic acid inhibits streptokinase-plasminogen activator complex formation and substrate binding through kringle-dependent mechanisms. Biochemistry. 39, 4740-4745

Borza, D. B. and Morgan, W. T. (1997) Acceleration of plasminogen activation by tissue plasminogen activator on surface-bound histidine-proline-rich glycoprotein. J Biol Chem. 272, 5718-5726 
Sodeinde, O. A., Subrahmanyam, Y. V., Stark, K., Quan, T., Bao, Y. and Goguen, J. D. (1992) A surface protease and the invasive character of plague. Science. 258, 1004-1007

49 Deitcher, S. R. and Eisenberg, P. R. (1993) Elevated concentrations of cross-linked fibrin degradation products in plasma. An early marker of gram-negative bacteremia. Chest. 103, 1107-1112

50 Gladysheva, I. P., Turner, R. B., Sazonova, I. Y., Liu, L. and Reed, G. L. (2003) Coevolutionary patterns in plasminogen activation. Proc Natl Acad Sci U S A. 100, 9168-9172

51 Parkkinen, J., Hacker, J. and Korhonen, T. K. (1991) Enhancement of tissue plasminogen activator-catalyzed plasminogen activation by Escherichia coli $\mathrm{S}$ fimbriae associated with neonatal septicaemia and meningitis. Thromb Haemost. 65, 483-486

Pesavento, P. A., Bannasch, M. J., Bachmann, R., Byrne, B. A. and Hurley, K. F. (2007) Fatal Streptococcus canis infections in intensively housed shelter cats. Vet Pathol. 44, 218-221 


\section{FIGURE LEGENDS}

Fig. 1. Plasminogen recruitment to $S$. canis and $S$. equisimilis after incubation with human plasma or purified radiolabelled plasminogen. A, Coomassie stain of plasma proteins eluted from streptococcal surface after plasma incubation. Arrow indicates the $90 \mathrm{kDa}$ plasminogen protein. B, Immunoblot analysis with plasminogen-specific antibodies after incubation of different $S$. canis (G1, G2, G14, G361) and S. equisimilis strains (C90) with human plasma. C, Coomassie stain of plasminogen recruitment to the human $S$. canis isolate G361 after incubation with plasma derived from pig (swine), goat (caprine), cat (feline), dog (canine), and human. D, Binding of ${ }^{125}$ I-labelled plasminogen to streptococci. Plasminogen binding was performed in triplicates and was calculated in percentage of employed iodinated plasminogen.

Fig. 2. Identification of plasminogen binding protein as M-like protein of S. canis. A, Amino acid sequence of $S$. canis M like protein SCM. Signal sequence (VKA-EH, in standard font), LPxTGmotif (written in italic letters), and the last amino acids of the $25 \mathrm{kDa}$ N-terminal part of SCM (SCM $25 \mathrm{KD}$, underlined). B, Circular dichroism (CD) spectrum showing molar ellipticity versus wavelength for native SCM. The value for 222:208 nm ratio is depicted. C, Alignment of the SCM with selected alpha-helical, coiled-coil proteins, including SpaSc of S. canis (ACM47242.1), SpaZ of S. equi sub. zooepidemicus(ACG63105.1), Spa of S. pyogenes (AAL98520.1), SzM of S. equi sub. zooepidemicus (CAW97903.1), Mrp4 of S. pyogenes (AAB33261.1), M18.1 of S. pyogenes (AAB03086.1), PAM of S. pyogenes (CAA80222.1), and M6 of S. pyogenes. The generalized heptad a-b-c-d-e-f-g sequence is depicted above the alignment; respective amino acids are indicated in grey. D, Illustration of PCR analysis of different $S$. canis isolates with oligonucleotides specific for $S$. canis scm gene. Positiv (+) and negativ (-) plasminogen binding of the respective strains is depicted below.

Fig. 3. Biochemical characterization of plasminogen binding of $S$. canis isolates and SCM protein. A, Plasminogen binding analysis of S. gordonii heterologously expressing SCM (SGO-SCM) was analysed with iodinated plasminogen. B, Dot blot overlay of recombinant $S$. canis M-like protein SCM and its N-terminal fragment SCM 25KD. SCM and SCM 25KD were immobilized in serial dilutions on nitrocellulose $(0.25 \mu \mathrm{g}, 0.125 \mu \mathrm{g}, 0.063 \mu \mathrm{g}$ and $0.031 \mu \mathrm{g})$ followed by incubation with iodinated human plasminogen. C-E, Sensograms of surface plasmon resonance kinetics of plasminogen binding to SCM (C) and to the N-terminal fragment of SCM 25KD (D). Plasminogen was immobilized on Biacore CM5 Sensorchips and both, SCM and SCM 25KD were used as analytes. E, Binding kinetic analysis after immobilization of SCM full length and with plasminogen as analyte.

Fig. 4. Binding analysis and inhibition studies of plasminogen and different plasminogen derivatives to different streptococci. A, Inhibition of lysine-dependent plasminogen binding to $S$. canis G361 in the presence of $0.001 \mathrm{mM}, 0.01 \mathrm{mM}, 0.1 \mathrm{mM}, 10 \mathrm{mM}, 100 \mathrm{mM}, 1000 \mathrm{mM}$ of lysine analogue 6-AHA. B, C, Inhibition of plasminogen binding of S. canis G361 (B) and S. pyogenes isolate A158 (C) by non-labelled plasminogen and non-labelled K1-3, respectively. Inhibitors were employed in concentrations of $0.5 \mu \mathrm{M}, 1.0 \mu \mathrm{M}, 1.5 \mu \mathrm{M}$ and $2.0 \mu \mathrm{M}$. D, Binding analysis of iodinated human K1-3 to S. canis, S. gordonii and S. pyogenes. E, Dot blot analysis of SCM binding to plasminogen and plasminogen derivatives: K1-3, angiostatin (representing K1-4), K4, and miniplasminogen (representing K5 and the catalytic domain). Plasminogen and its fragments were immobilized on nitrocellulose in an amount of $3.0 \mu \mathrm{g}, 1.5 \mu \mathrm{g}, 0.75 \mu \mathrm{g}, 0.38 \mu \mathrm{g}$ and $0.19 \mu \mathrm{g}$. Binding of SCM was detected with SCM-specific antibodies and HRP-conjugated secondary antibodies. 
Unspecific cross-reactivity of antibodies was not detected (data not shown). F, Kinetic analysis of SCM binding to immobilized mini-plasminogen using surface plasmon resonance technique.

Fig. 5. Plasmin activation mechanism of $\boldsymbol{S}$. canis strain G361. A, B, Determination of secreted plasmin activity by measurement of chromogenic plasmin substrat S-2251 at $405 \mathrm{~nm}$ in a time series including $0 \mathrm{~min}, 30 \mathrm{~min}, 90 \mathrm{~min}$ and $120 \mathrm{~min}$ after incubation of $S$. canis G1, G2, G361 and $S$. equisimilis C90 with human plasma (A) and canine plasma (B). C, Plasmin activity was measured after incubation of $S$. canis bacteria with purified human plasminogen in the presence of urokinase. Plasmin activity was determined over a time period up to $120 \mathrm{~min}$ and also in the presence of the serine protease inhibitor aprotinin. D, Dose-dependent inhibition of plasmin activation by the addition of $2.0 \mathrm{mM}, 40 \mathrm{mM}$ and $80 \mathrm{mM}$ of the lysine analogue 6-AHA. E, Time dependent conversion of plasminogen bound to surface of SCM-expressing SGO and soluble plasminogen. No plasmin activation was detected without plasminogen or urokinase, respectively (data not shown).

Fig. 6. Plasmin-mediated degradation of fibrinogen and fibrin matrices by S. canis G361. A, Immunoblot analysis of degradation of human fibrinogen by plasminogen encoated $S$. canis G361 bacteria. Degradation was analysed in the presence of urokinase after indicated time points $(0 \mathrm{~min}, 5$ min, $10 \mathrm{~min}, 20 \mathrm{~min}, 30 \mathrm{~min}$, and $60 \mathrm{~min}$ ) with fibrinogen-specific antibodies. Fibrinogen was not degraded after incubation of plasminogen-coated $S$. canis for $0 \mathrm{~min}$ and for $60 \mathrm{~min}$ with fibrinogen without activator (Ctrl 0, Ctrl 60). B, Illustration of plasminogen-mediated degradation of fibrin generated on a porous transwell membrane by S. canis G361 in the presence or absence of urokinase. Plasmin-mediated transmigration of $S$. canis 361 through fibrin clots was quantified by determination of bacterial $\mathrm{cfu} \cdot \mathrm{ml}^{-1}$ after different incubation periods $(0 \mathrm{~h}, 2 \mathrm{~h}, 4 \mathrm{~h}, 6 \mathrm{~h})$ by plating of serial dilutions from the lower well. C, Time-lapse imaging of fibrin degradation by plasmin-encoated S. canis G361 bacteria. S. canis G361 bacteria (arrows) are visible within the dissolved fibrin solution.

Fig. 7. Visualization of fibrin degradation by plasmin-coated S. canis G361 and S. gordonii bacteria analysed by field emission scanning electron microscopy (FESEM). A, B, Microscopic images illustrate a dense network of microthrombi formed by bundled fibrin fibres (control). C-E, Bacterial attachment to the fibrin matrix was shown by non-treated S. canis G361 (C, D) as well as by plasminogen-preincubated bacteria (E, PLG). F-H, The fibrin bundles were degraded by proteolytic active $S$. canis bacteria in the presence of urokinase (PLG, uPA). I, J, Only minor bacterial attachment to fibrin thrombi was detected by $S$. gordonii lacking the SCM protein on the surface (I, SGO WT, white arrows) and plasminogen-preincubated SGO WT (J; SGO WT PLG, white arrows). K-M, No degradation of fibrin bundles was observed with plasmin-encoated S. gordonii (K, L; PLG, uPA) or SCM-expressing S. gordonii (SGO-SCM) without plasminogen incubation (M; PLG). N, Plasminogen preincubation was not mediating microthrombi dissolution by SGO-SCM. O, P, Remarkable degradation of fibrin bundles was only detected by S. gordonii expressing the SCM protein on its surface (SGO-SCM) supplemented with plasminogen and urokinase (PLG, uPA). 


\section{TABLE 1}

Bacterial strains

\section{$\underline{\text { Isolate }}$}

G1

G2

G8

G13

G14

G15

G17

Sc1 4074- $03^{\mathrm{a}}$

Sc2 6381-02 ${ }^{\mathrm{a}}$

Sc3 8881- $03^{\mathrm{a}}$

Sc4 5426- $05^{\mathrm{a}}$

G361

$39126 / 96^{\mathrm{c}}$

$2572^{\mathrm{c}}$

$2424 / 96^{\circ}$

$1022 / 96^{\mathrm{C}}$

$2424^{\mathrm{c}}$

$566714^{\mathrm{c}}$

$734 / 95^{\mathrm{c}}$

C90

A158

\section{Strains}

S. canis

S. canis

S. canis

S. canis

S. canis

S. canis

S. canis

S. canis

S. canis

S. canis

S. canis

S. canis

S. canis

S. canis

S. canis

S. canis

S. canis

S. canis

S. canis

S. equi sub. equisimilis (GCS3)

S. pyogenes (PAM)
Host

$\operatorname{dog}$

$\operatorname{dog}$

$\operatorname{dog}$

dog

dog

dog

dog

human

human

human

human

$\operatorname{dog}$

$\operatorname{dog}$

$\operatorname{dog}$

dog

dog

dog

dog

dog

human

human

${ }^{a}$ B.W. Beall, Centers for Disease Control and Prevention, Atlanta, Georgia, USA

${ }^{\mathrm{b}}$ M. van der Linden, National Reference Centre for Streptococci, Aachen, Germany

${ }^{\mathrm{c}}$ J.F. Presocott, Department of Pathobiology, University of Guelph, Ont., Canada

\section{TABLE 2}

Kinetic parameters of Biacore Sensogram

\begin{tabular}{llcccc} 
ligand & analyte & $\begin{array}{c}\mathbf{k}_{\mathbf{a}} \\
(\mathbf{1} / \mathbf{M s})\end{array}$ & $\begin{array}{c}\mathbf{k}_{\mathbf{d}} \\
\mathbf{( 1 / s )}\end{array}$ & $\begin{array}{c}\mathbf{k D} \\
\mathbf{( M )}\end{array}$ & $\boldsymbol{\chi}^{\mathbf{2}}$ \\
\cline { 3 - 6 } $\mathrm{PLG}$ & $\mathrm{SCM}$ & $5.76 \mathrm{e}^{3}$ & $1.55 \mathrm{e}^{-4}$ & $2.69 \mathrm{e}^{-8}$ & 20 \\
PLG & SCM25KD & $1.10 \mathrm{e}^{4}$ & $2.28 \mathrm{e}^{-4}$ & $2.07 \mathrm{e}^{-8}$ & 4 \\
mPLG & SCM & $9.63 \mathrm{e}^{3}$ & $1.33 \mathrm{e}^{-4}$ & $1.38 \mathrm{e}^{-8}$ & 16 \\
SCM & PLG & $3.11 \mathrm{e}^{3}$ & $1.59 \mathrm{e}^{-3}$ & $5.10 \mathrm{e}^{-7}$ & 27.7
\end{tabular}




\section{Figure 1}

A

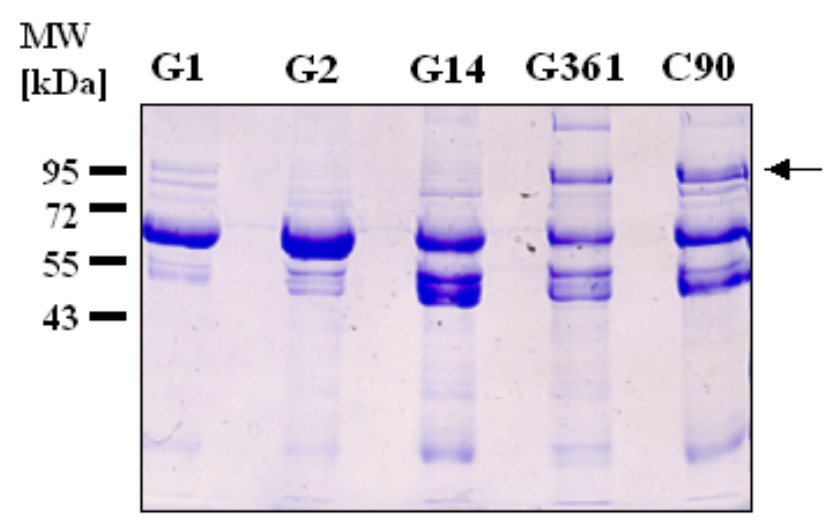

C

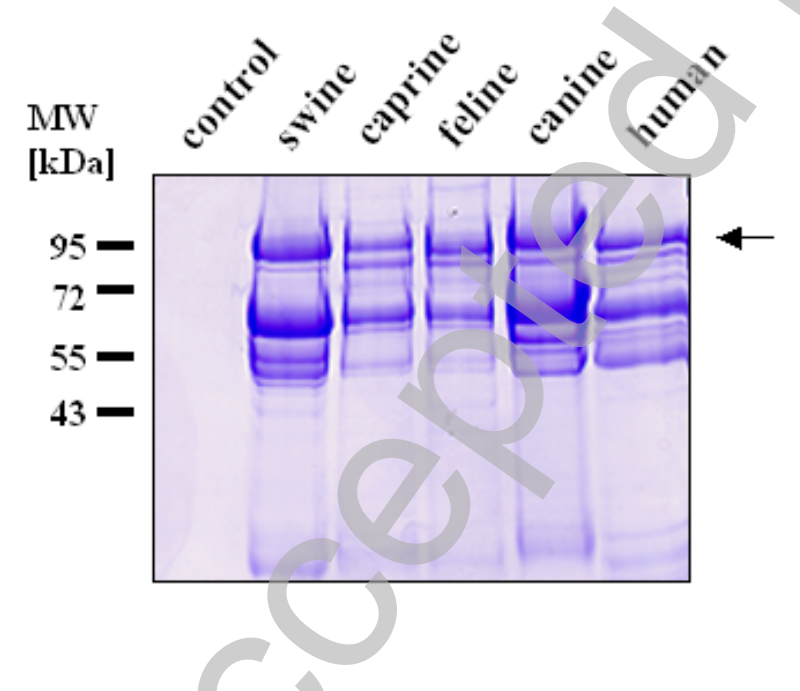

B

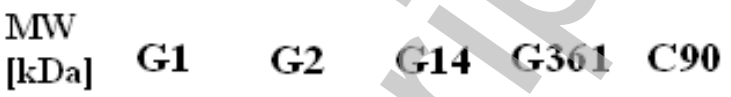

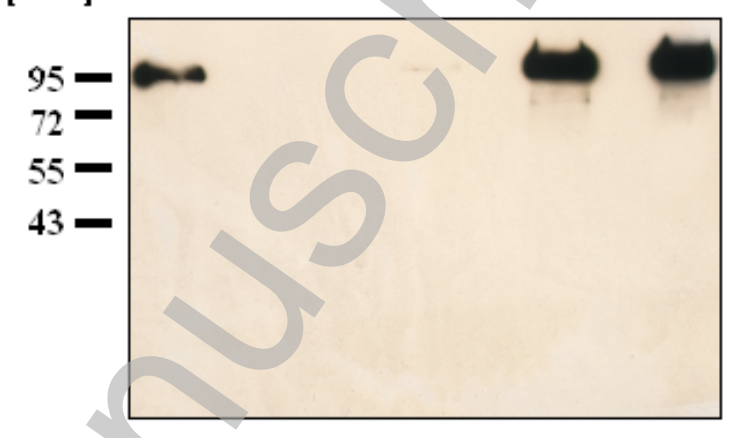

D

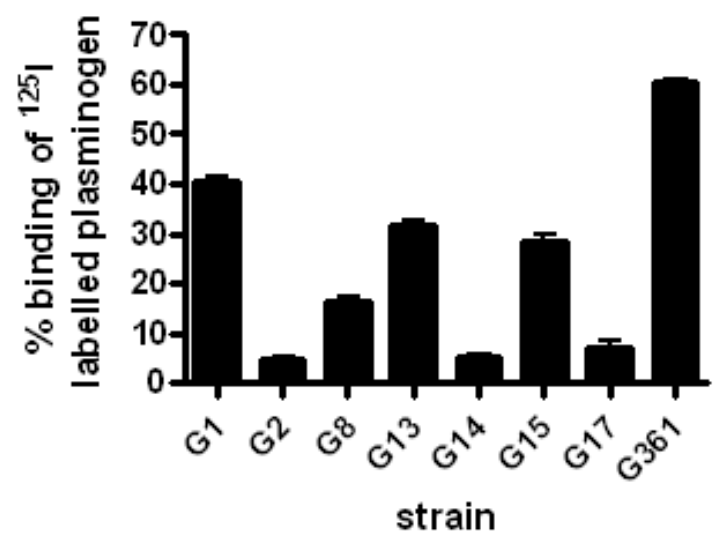




\section{Figure 2}

A

MTRKKTTKKLSUGTASLLAATTULGAATTT

TVKAEHIRVTEARASVLRHSWPSSF WYRE

VLKRDHLRKEVKYLEDLVRSEVEDYRKL VG HTDMIEKELLRTTDSLRVTE 0HIKGL TKEK SLLTDSLE TTKKALEDSOKE AOARLD FL.FH KNEOIASL VGERDSLSAOLS ASOERW AFLE RHLESYDRLIESAKFEMOOKL AETERLTAE KADAKDOIEKL QFEVSTLRD QVASLDRLVE SAKYDLAOKOAEID TLTKOKAEAEOAL AЯE OAKVAELEKOKAEAEAKI YVLEKDLE TAOA EH AKYKE QLAKOAEELEAЯKKAKAEAEЯKT EELKGILDKKAODHASLQAE TIRLKOGISD KMKSIMPOGTAKARISSTDAKKDSHOLPST GE AAHPFF TAA
Ho. of aa

30
60
90
120
150
180
210
240
270
300
330
360
390
401

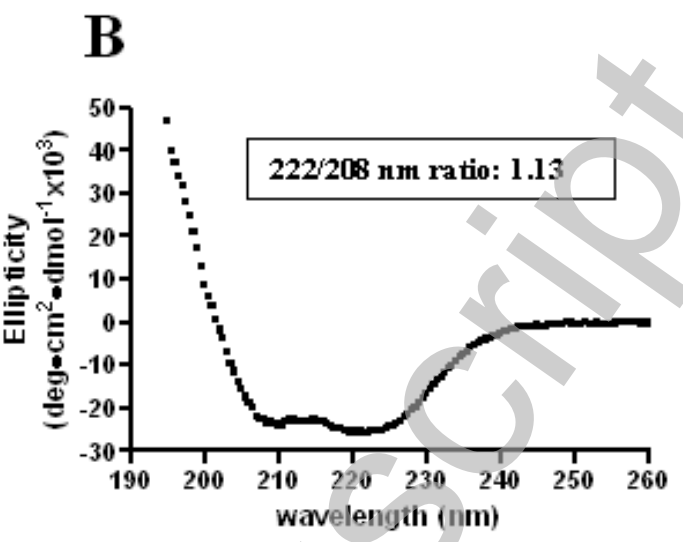

C

gabcde $f g a b c d e f g a b c d e f g a b c d e f g a b c d e f g a b c d e f g a b c d e f g a b c d e f g a b c$

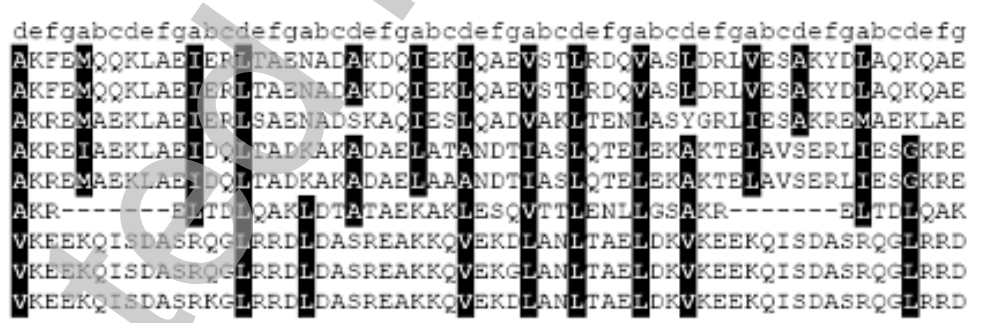

D


\section{PL G binding}




\section{Figure 3}

\section{A}

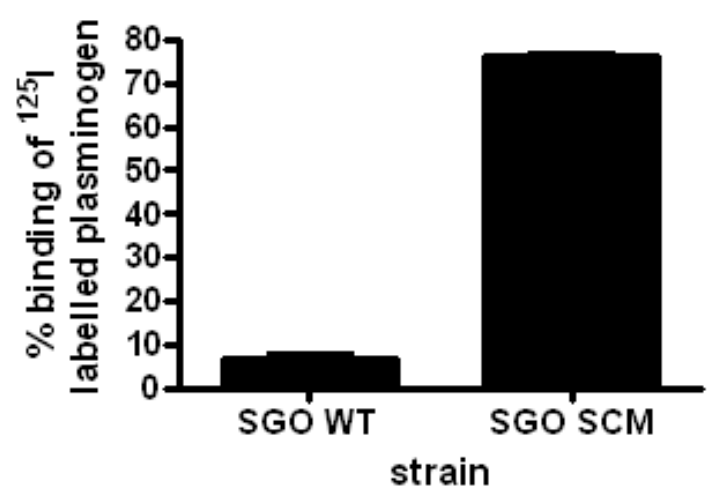

C
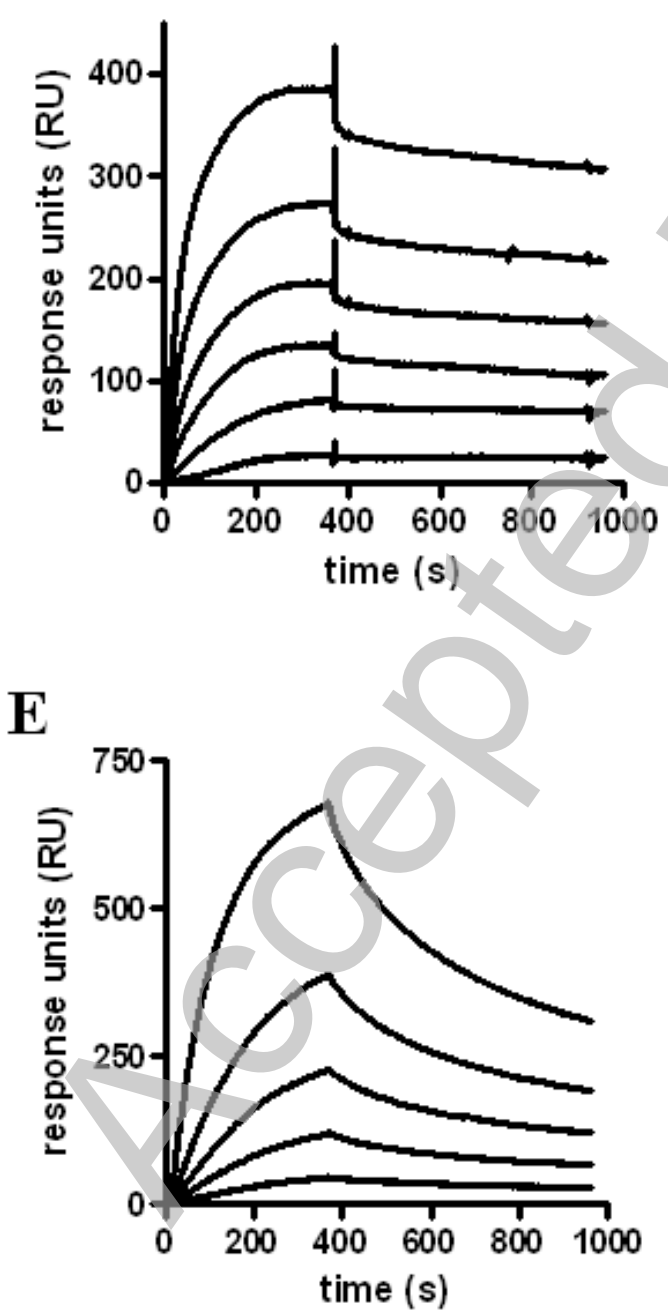

\section{B}
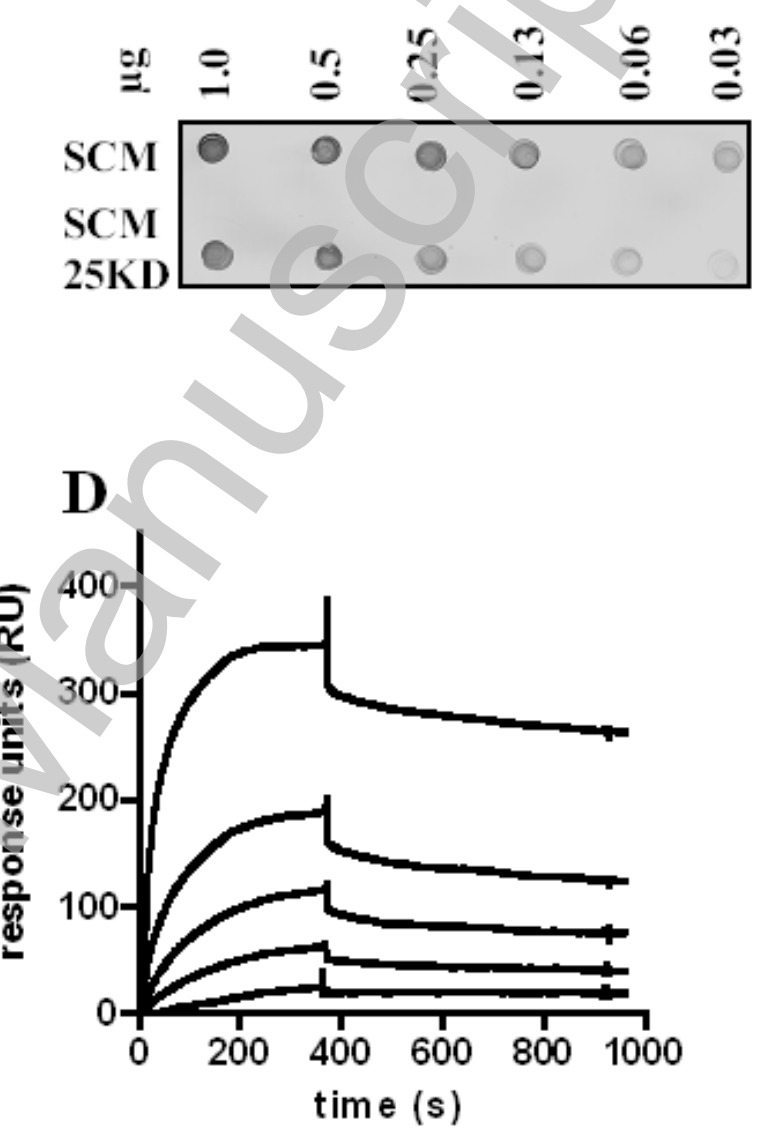


\section{Figure 4}

A

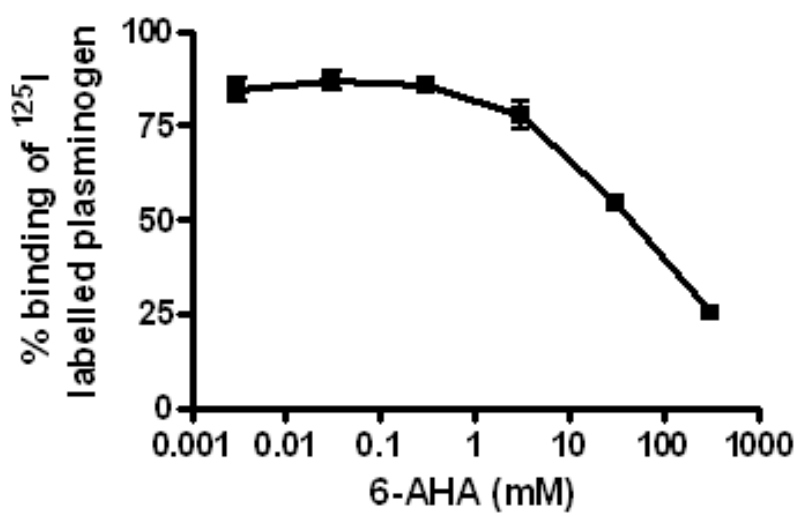

B

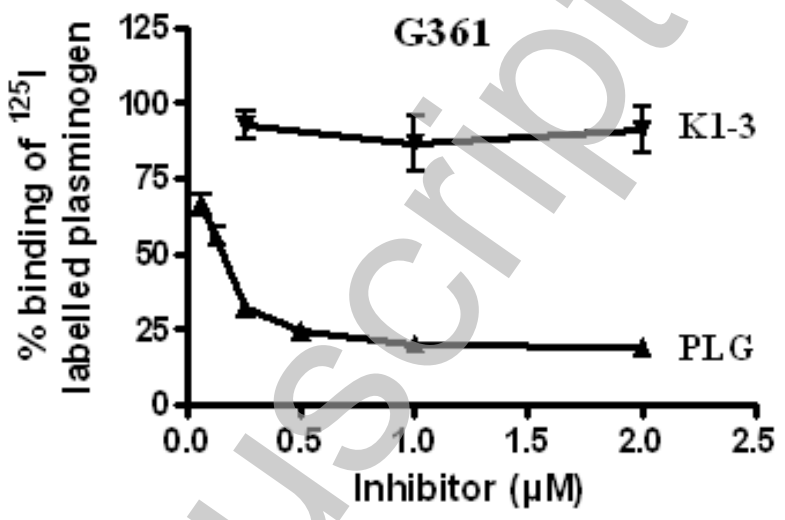

D

C

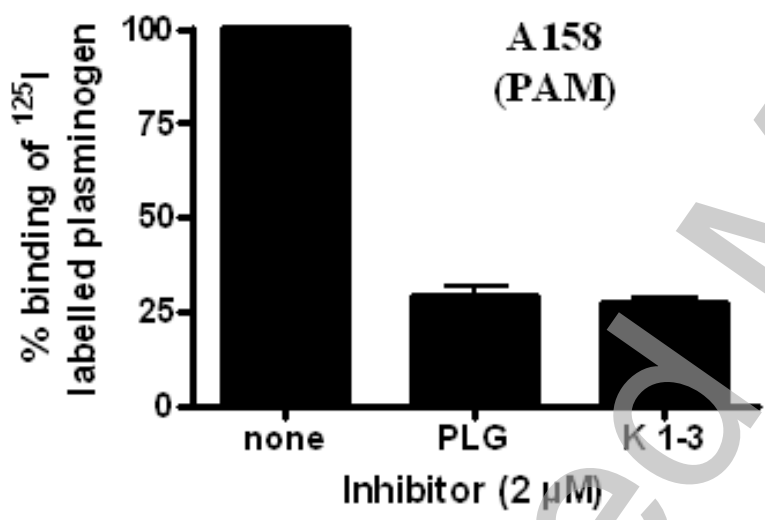

$\mathbf{E}$

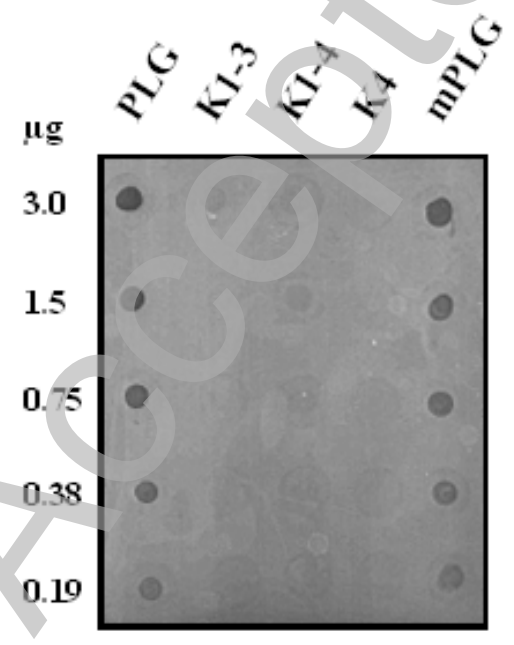

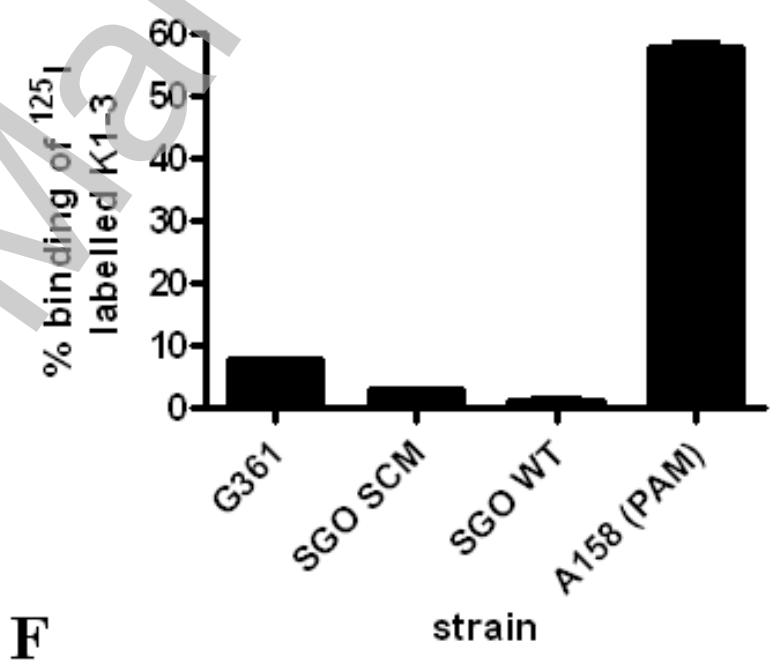

$\mathbf{F}$

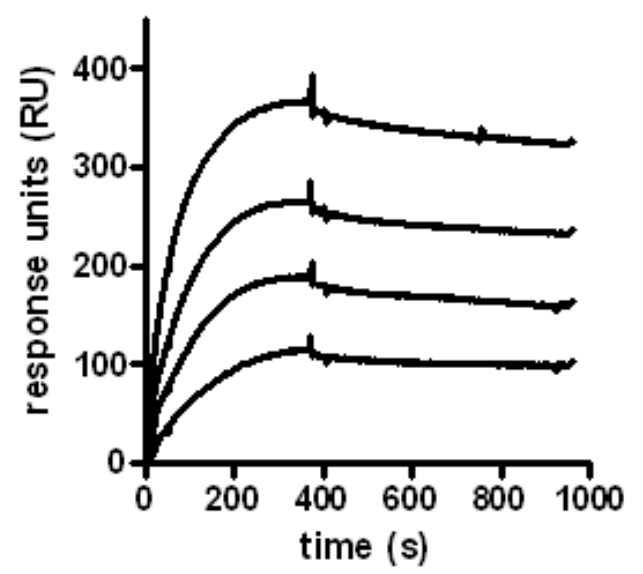




\section{Figure 5}

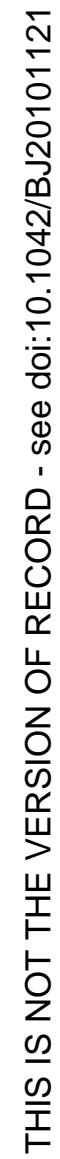
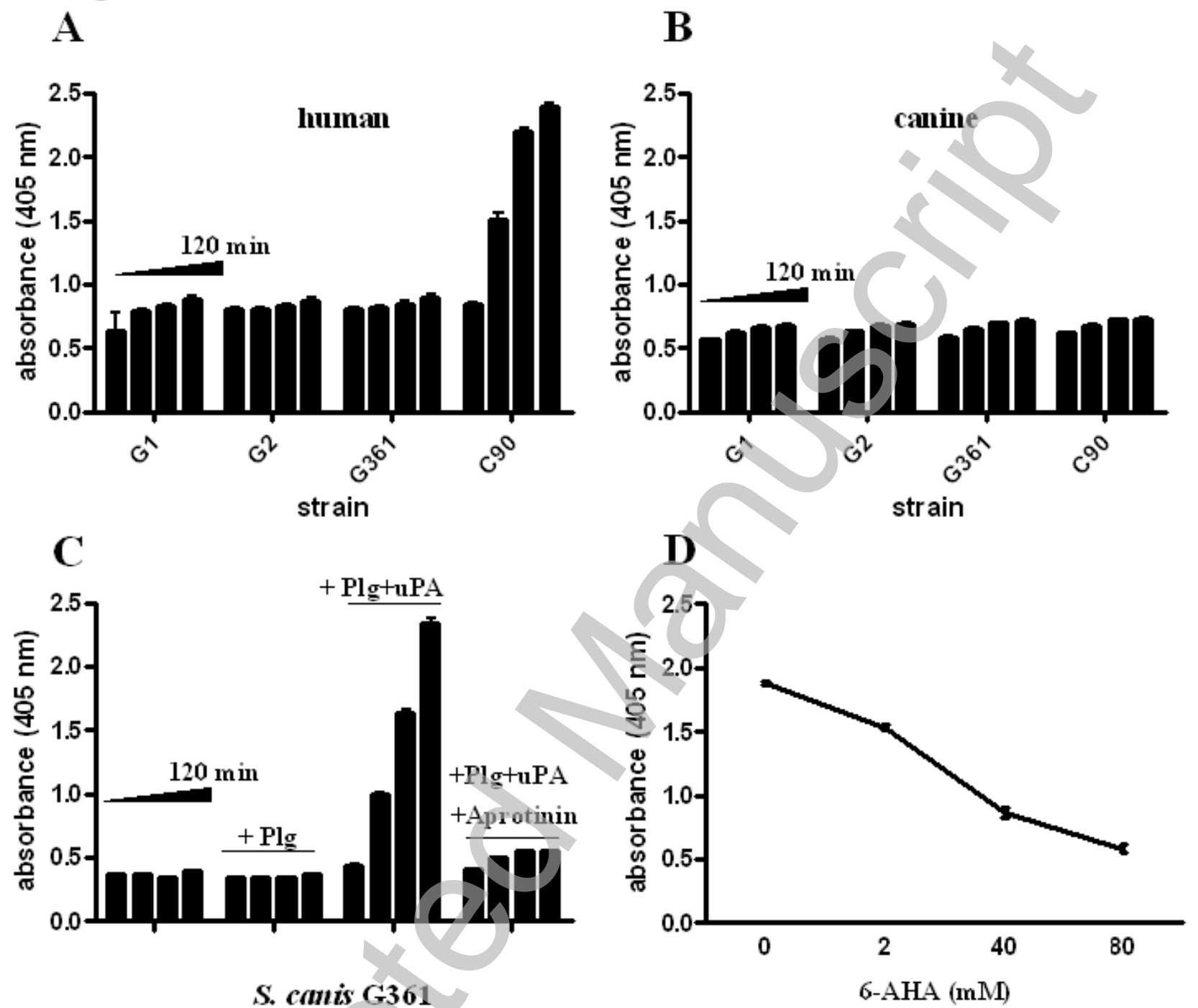

\section{S. canis G361}






\section{Figure 6}

A

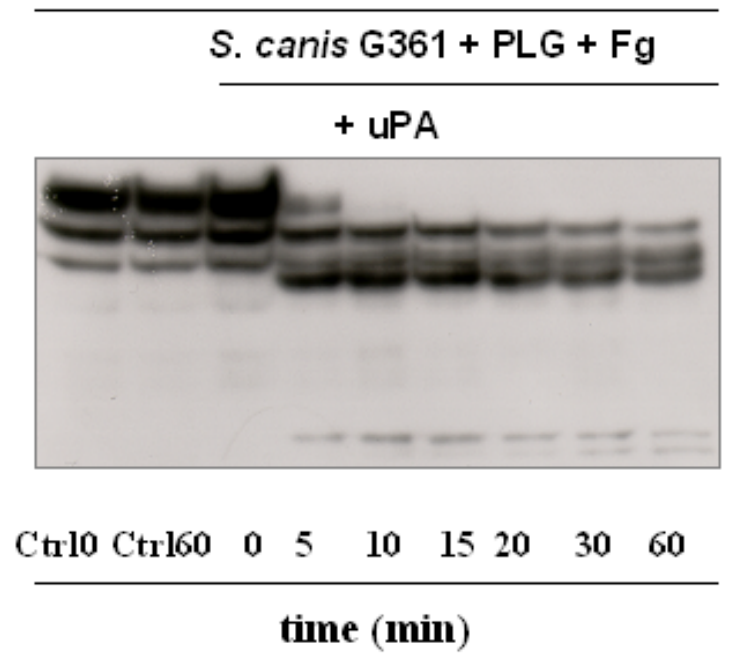

C



tine (mill)
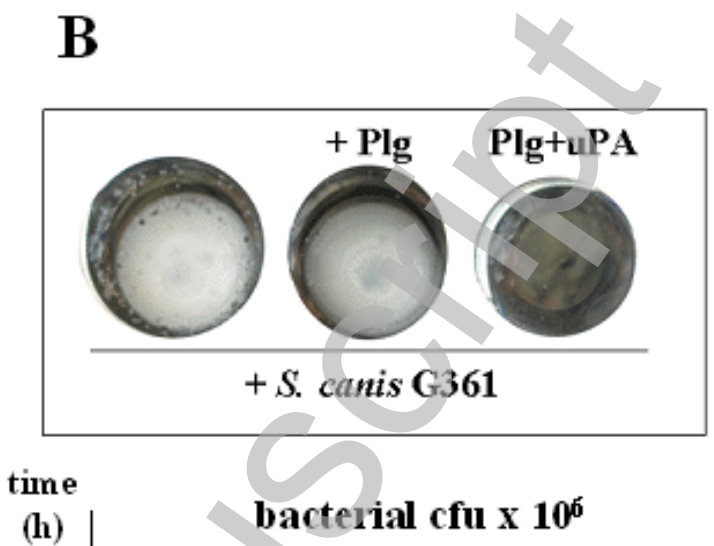

\begin{tabular}{c|ccc} 
(h) & \multicolumn{3}{|c}{ bacterial cfu x $\mathbf{1 0}^{\mathbf{6}}$} \\
\hline 0 & 0 & 0 & 0 \\
2 & 0 & 0 & 0 \\
4 & 0 & 0 & $3.7 \pm 0.7$ \\
6 & 0 & 0 & $8.3 \pm 0.8$
\end{tabular}

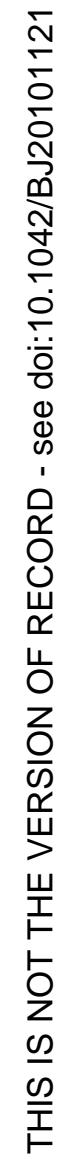
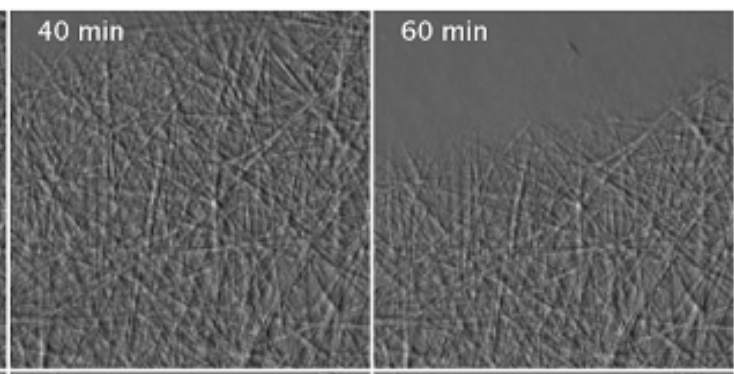

$120 \mathrm{~min}$




Biochemical Journal Immediate Publication. Published on 06 Jan 2011 as manuscript BJ20101121

\section{Figure 7}



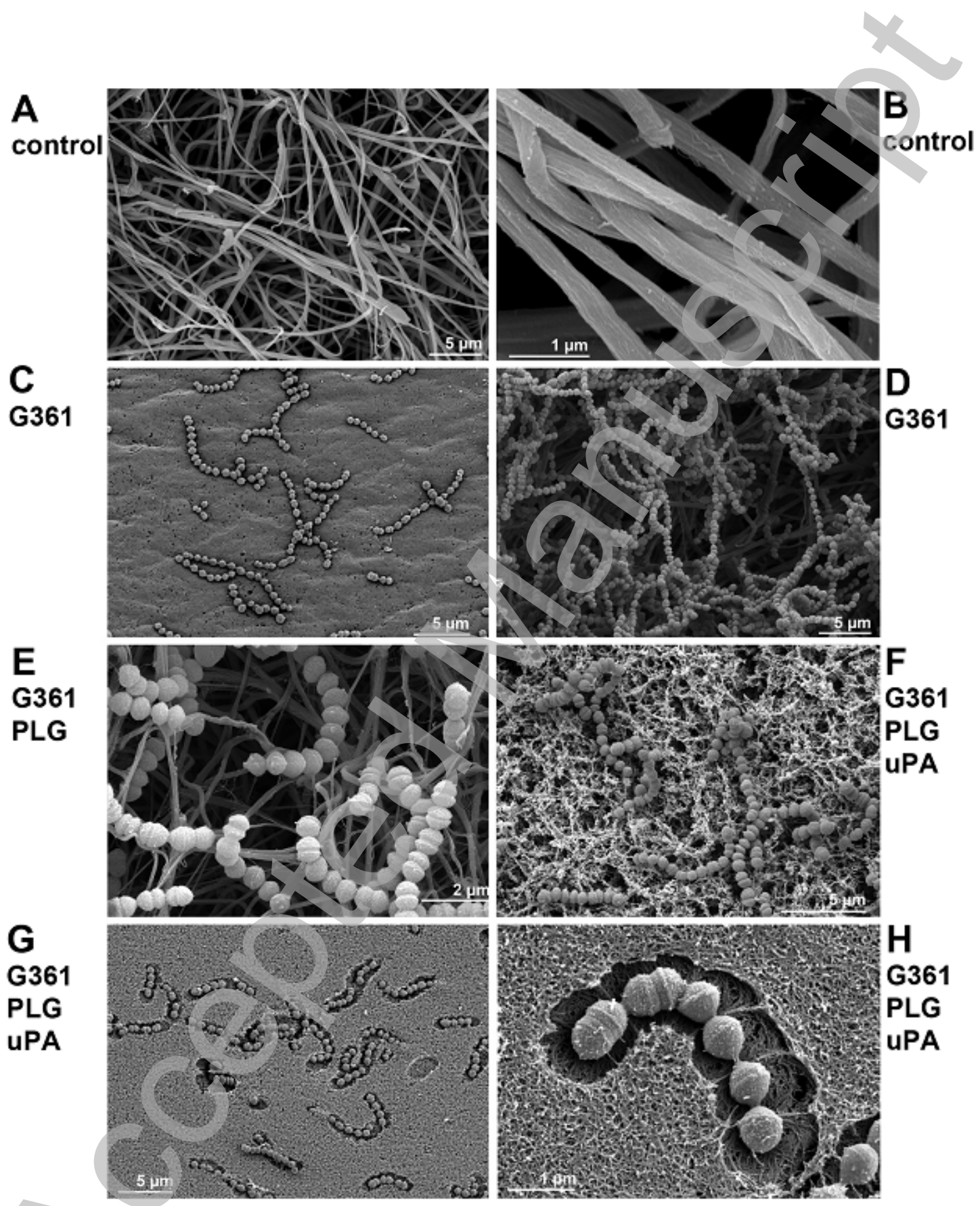


Biochemical Journal Immediate Publication. Published on 06 Jan 2011 as manuscript BJ20101121

\section{Figure 7}



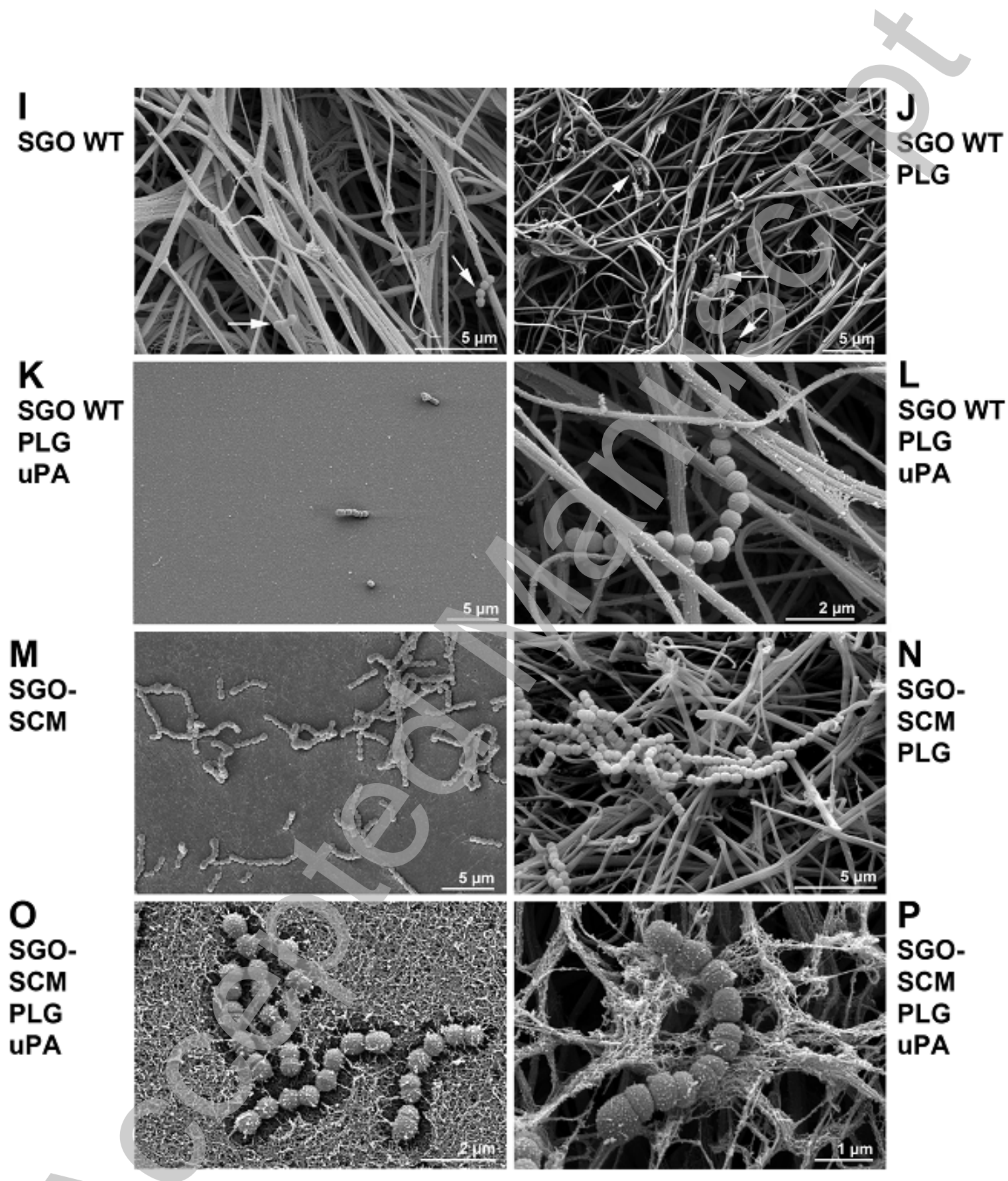


